\title{
Survival of eclogite xenolith in a Cretaceous granite intruding the Central Dabieshan migmatite gneiss dome (Eastern China) and its tectonic implications
}

\author{
Wei Lin ${ }^{1}$, Masaki Enami ${ }^{2}$, Michel Faure ${ }^{3}$, Urs Schärer ${ }^{4}$ and Nicolas Arnaud ${ }^{5}$
}

(1) State Key Laboratory of Lithosphere Tectonic Evolution, Institute of Geology and Geophysics, Chinese Academy of Sciences, PO Box 9825, Beijing, 100029, China

(2) Department of Earth and Planetary Sciences, Nagoya University, Chikusa-ku, Nagoya 464-8602, Japan

(3) Institut des Sciences de la Terre d'Orléans, Université d'Orléans, 45067 Orleans Cedex 2, France

(4) UMR Géosciences Azur, Université Nice-Sophia Antipolis, parc Valrose, Nice, France

(5) UMR Dylith, Université de Montpellier II, 34060 Montpellier Cedex 5, France

\begin{abstract}
Investigation of an eclogite xenolith, discovered in a Cretaceous granite from the Central Domain of the Dabieshan massif in eastern China, yields new petrological insights into the high to ultrahigh-pressure metamorphism, experienced by the Qinling-Dabie orogen. Prior to inclusion as a xenolith in the granite during the Early Cretaceous, this eclogite xenolith had recorded a complex metamorphic evolution that complies with subduction and exhumation processes experienced by the continental crust of the South China Block. Well-preserved mineral parageneses substantiate the prograde and retrograde stages revealed by inclusions in porphyroblastic garnet and zoned minerals such as garnet, omphacite and amphibole in the matrix. The relatively low $\mathrm{P} / \mathrm{T}$ re-equilibration during a late metamorphic stage was textually inferred by the presence of aluminous and calcic-subcalcic amphiboles such as katophorite, edenite, taramite and pargasite as main matrix phases. According to our $\mathrm{U} / \mathrm{Pb}, \mathrm{Rb} / \mathrm{Sr}$ and new ${ }^{40} \mathrm{Ar} /{ }^{39} \mathrm{Ar}$ geochronological results, namely $109 \pm 1$ and $112 \pm 2$ Ma plateau ages for muscovite and amphiboles, respectively, two successive but distinct cooling stages account for the thermal history of the granite-migmatite gneiss dome that forms the Central Dabieshan Domain. We argue that prior to the Cretaceous doming, the Central Dabieshan Domain experienced a tectono-metamorphic evolution similar to that observed in the high-pressure to ultra high-pressure units developed in the Southern Dabieshan Domain and Hong'an massif.
\end{abstract}

Keywords : Eclogite xenolith - Mesozoic granite - Radiometric ages - Exhumation model Dabieshan - China 


\section{Introduction}

Eclogite xenoliths, classified as "A-type" eclogites (Coleman et al. 1965; Carswell 1990), included in volcanic rocks are common worldwide, and most of them are lower crustal or mantle mafic rocks, scavenged by magma ascending from the mantle (Nixon 1987; Griffin et al. 1990). Conversely, eclogite xenoliths in post-collisional granitoids are rare. Nevertheless, these rocks provide excellent probes of middle to lower crust for understanding intraplate processes and the tectonic course of exhumation of high-pressure (HP)-ultrahigh-pressure (UHP) metamorphic rocks. HP to UHP metamorphic rocks derived from continental or oceanic protoliths are now commonly found in convergent zones (Carswell 1990; Ernst and Liou 1999; Coleman and Wang 1995). They usually record HP and relatively low temperature equilibria and are believed to have been buried at lower crust or mantle depths in a subduction zone setting. In most collisional zones, HP and UHP metamorphic rocks crop out as boudins in gneiss or as coherent structural unit (i.e. nappes or klippen). Moreover, these HP and UHP metamorphic rocks underwent rapid exhumation in order to preserve HP or UHP assemblages up to the Earth's surface. However, eclogitic xenolith included in late to post-orogenic plutons are rarely described, probably due to the fact that heat and fluid migration associated with magmatism lead to a complete retrogression of the UHP or HP assemblages into amphibolite or even greenschist facies assemblages.

In eastern China, the Qinling-Dabie Belt corresponds to the collision zone between the North China block (NCB) and the South China block (SCB) (e.g. Mattauer et al. 1991; Okay et al. 1993; Cong and Wang 1994). Since the discovery of UHP metamorphic rocks containing coesite at the end of 1980s, research in the Dabieshan has been very intense (e.g. Cong and Wang 1999 and enclosed references). In spite of these petrological and geochemical advances, structural and tectonic investigations of the Dabieshan remain rare. Knowledge of the regional tectonic framework of the HP-UHP metamorphism, based on structural field surveys and understanding of the geodynamic setting of the UHP metamorphism inferred from geological data of the eclogites, are far from complete. Granulitic (Zhang et al. 1996) and eclogitic xenoliths (sensu lato) included in ultramafic complex (Tsai and Liou 2000; Xiao et al. 2001) have been rarely reported from other localities in the northern Dabieshan Domain, moreover, their petrogenesis is not well understood yet.

In this study, we report the petrology of an eclogite xenolith discovered within a Mesozoic granite in the Central Domain of the Dabieshan massif, and discuss new ${ }^{40} \mathrm{Ar} /{ }^{39} \mathrm{Ar}$ mineral and previous $\mathrm{U} / \mathrm{Pb}, \mathrm{Rb} / \mathrm{Sr}$ ages of the host granite that place chronological constraints for the dome building in Early Cretaceous times. Garnet inclusions and zonal structures of garnet and amphibole well preserve the mineral parageneses related to the prograde metamorphic stage. These petrological and mineralogical features allow us to argue that the Central Dabieshan Domain experienced a tectonic evolution similar to the HP-UHP units of the Southern Dabieshan Domain and Hong'an massif (Fig. 1) before the formation of the Cretaceous migmatitic dome

\section{Geological setting}

On the basis of several years of fieldwork, we consider that the Dabieshan massif can be subdivided into three parts: the Southern, Central and Northern domains (Fig. 1). The Southern Dabieshan Domain forms a southward dipping stack of tectonic units including, from bottom to top, an eclogite-free gneiss unit, an UHP eclogite nappe, a HP metamorphic 
unit developed from Proterozoic protoliths, and a sedimentary cover ranging in age from NeoProterozoic to Early Triassic (Faure et al. 1999, 2003). The Central Dabieshan Domain was previously considered as an "eclogite free unit" (Cong and Wang 1996) and was variously interpreted as a thermal overprinted subduction complex (Wang and Liou 1991; Okay and Sengör 1992), a metamorphic ophiolite mélange (Xu et al. 1992, 1994), an andean-type margin magmatic arc complex (Zhai et al. 1994) or a Cretaceous magmatic belt called the Northern Orthogneiss Unit (NOU, Hacker et al. 1998). Moreover, the lack of ophiolites along the Xiaotian-Mozitan fault, which is the northern boundary of the Central domain (Fig. 1), shows that this fault does not correspond to a plate boundary (Hacker et al. 1998). The Beihuaiyang complex, which consists of the Foziling and Luzhenguan complexes, forms the real north part of the Dabieshan massif (Okay et al. 1993; Lin et al. 2005a, b). Consequently, we prefer to label this unit "Central Dabieshan Domain" instead of Northern Orthogneiss Unit (NOU).

Geometrically, the Central Dabieshan Domain is a $100-\mathrm{km}$-scale dome, mostly occupied by migmatite and plutonic rocks (Figs. 1,2 ). In the dome, two types of migmatites are distinguished. The central part of the dome consists of diatectic migmatites with a relatively weakly developed foliation marked by schlieren, and a weakly preferred orientation of metamorphic xenoliths (Fig. $\underline{3}$ a). Conversely, along the dome margin, the migmatites are gneissified under subsolidus conditions and develop mylonitic to ultramylonitic fabrics. The gneissic migmatites exhibit conspicuous foliation and lineation structures (Fig.3b). Systematic measurements of the migmatitic foliations allow us to decipher the geometry of this migmatitic dome, which is well exposed around Luotian city (Fig.1). This dome is asymmetric and its southern and southeastern boundaries are wider and dip more gently than the northern and western ones (Fig.2). Developments of nebulitic structure, contorted leucosomes and common occurrences of augen gneiss unmelted parts of the metamorphic protolith with K-feldspar megacrysts and mafic blocks argue for an origin of the migmatites by partial melting of previous metamorphic rocks. The plutonic rocks in the Central Dabieshan Domain are granodiorite, tonalite and gabbro, which locally show a porphyritic texture. Some of these plutons usually have a foliated core and a gneissic or mylonitic border (BGMR-Anhui 1987; BGMR-Hubei 1990). In the field, due to their conspicuous foliation, the granitic plutons are not easily distinguished from the anatectic granitoids coeval with the migmatite. Radiometric $\mathrm{U} / \mathrm{Pb}$ and ${ }^{40} \mathrm{Ar} /{ }^{39} \mathrm{Ar}$ datings of the granitoids indicate Cretaceous ages (ca 140-130 Ma, Eide et al. 1994; Xue et al. 1997; Hacker et al. 1998). Moreover, xenoliths of amphibolite are frequently included in these Cretaceous plutons. The well-preserved eclogite xenolith described in this paper was discovered within granitic rocks in the Central Dabieshan Domain in the north of Luotian city (Fig.1). In this unique granitic outcrop of about $5 \mathrm{~m}^{2}$, only one single eclogitic block was present among several dozen of metabasite xenoliths that are mostly amphibolite (Fig.3c).

\section{Petrography}

The eclogite xenolith included in granite is a few centimeters in size, and is petrologically and mineralogically similar to the typical "cold eclogite (HP eclogite)" of Okay et al. (1993). It is medium-coarse grained and contains major matrix phases of garnet, omphacite, glaucophane, barroisite, epidote, rutile and quartz (Fig.4). Garnet contains epidote, rutile and quartz as major inclusions and chlorite as a minor phase. Barroisitic amphibole and omphacite are rarely found as inclusions in the core and mantle parts of garnet, respectively. Glaucophane is rimmed by winchite/barroisite (Fig. 4). The zoned sodic-subcalcic amphiboles in the matrix are partly mantled (Fig. 4) or veined (Fig. 5) by katophorite and less silicic amphiboles. The matrix omphacite contains needle-like lamellae of quartz and minor amounts of rutile (Fig. 6). 
During exhumation or later stages of heating, matrix omphacite was partly replaced by barroisite/edenite and albite along cleavages or around rims. Garnet is mantled by pargasite. Epidote occurs both as inclusion in garnet and as a matrix phase. Titanite retrogressively rims prograde rutile.

In the figures and tables, abbreviations for minerals and end-members follow Kretz (1983) and Miyashiro (1994), other are Ae (Aegirine), Bar (barroisite), Kat (katophorite) and Tar (taramite). Mineral formulae used for description of reaction relations follow Holland and Powell (1998). Abbreviations for element-sites for amphibole are: [6], octahedral M2-sites; [B], decahedral B-sites; and [A], 10-coordinated A-site.

\section{Mineral chemistry}

Quantitative analyses and X-ray mapping were carried out using a JEOL JXA-8800R electron-probe microanalyzer (EPMA) with Wave-dispersive-spectrometry (WDS) and Energy-dispersive-spectrometry (EDS) systems at the Petrological Laboratory of Nagoya University. Accelerating voltage, specimen current and beam diameter for quantitative analyses were $15 \mathrm{kV}, 12 \mathrm{nA}$ on the Faraday cup and 2-3 $\mu \mathrm{m}$, respectively. Well-characterized natural and synthetic phases were used as standards. The ZAF method was employed for matrix correction. For garnet, all iron was assumed to be ferrous and its end-member proportion $\left(X_{i}\right)$ was calculated as $i /(\mathrm{Fe}+\mathrm{Mn}+\mathrm{Mg}+\mathrm{Ca})$. The ferric iron content of sodic pyroxene was estimated as $\mathrm{Fe}^{3+}=\mathrm{Na}-\mathrm{Al}$ assuming a negligible amount of tschermakite substitution due to low-temperature estimates for the peak metamorphic stage such as discussed in the following section. Thus the end-member proportions of sodic pyroxenes were calculated as follows: $X$ jd $=\mathrm{Al}, X_{\text {ae }}=\mathrm{Fe}^{3+}$ and $X$ aug $=1-\left(\mathrm{Al}+\mathrm{Fe}^{3+}\right)$. Amphibole nomenclature follows Leake et al. (1997). $\mathrm{Fe}^{3+} / \mathrm{Fe}^{2+}$ ratios of amphiboles were calculated with total cations $=13$ excluding $\mathrm{Ca}, \mathrm{Ba}, \mathrm{Na}$ and $\mathrm{K}(\mathrm{O}=23)$. This is based on the fact that $\left(\mathrm{Fe}^{2+}+\mathrm{Mn}+\mathrm{Mg}\right)$ in the octahedral M(4) sites of sodic amphiboles is usually low in HP/LT metamorphic rocks (Deer et al. 1997).

\section{Garnet}

Garnet shows weak but bell-shaped chemical zoning in the spessartine component, which decreases in abundance from core towards the rim (Fig.7). Almandine and pyrope contents and $[\mathrm{Mg} \#=\mathrm{Mg} /(\mathrm{Mg}+\mathrm{Fe})]$ value increase all outwards and, the garnet can be interpreted to have formed during the prograde stage. Grossular content is fairly constant in the garnet core and decreases at crystal margins, and thus garnet is divided into Ca-rich core and relatively Ca-poor mantle parts. Compositional ranges of the garnet are $X_{\text {alm }} 0.56-0.65, X_{\text {prp }} 0.04-0.16$, $X_{\text {grs }} 0.21-0.33$ and $X$ sps $0.01-0.08$ (Fig.8, Table 1). $\mathrm{TiO}_{2}$ contents are less than $0.2 \mathrm{wt} \%$.

\section{Sodic pyroxene}

Most of the sodic pyroxenes in the matrix show a zonal structure with increasing $X_{\mathrm{jd}}$ and decreasing $X_{\text {ae }}$ from core to mantle (Fig. 9). The zoned grains are sometimes mantled by a relatively jadeite-poor outermost rim. The matrix sodic pyroxenes have a relatively wide compositional range of $X$ jd $0.29-0.43, X_{\text {aug }} 0.43-0.56, X_{\text {ae }} 0.05-0.20$ (Fig. 10). Their $\mathrm{Mg \#}$ value is also variable from 0.78 to 0.91 . Sodic pyroxenes included in the mantle part of garnet are almost homogeneous, and have composition ranges of $X{ }_{\mathrm{jd}} 0.38-0.41, X_{\text {aug }} 0.44-0.52, X$ ae $0.07-0.17$ and $\mathrm{Mg} \#=0.81-0.82$, which overlap those of jadeite-richer rims of matrix phases (Fig. 10, Table 1). $\mathrm{TiO}_{2}$ and $\mathrm{MnO}$ contents are less than 0.3 and $0.1 \mathrm{wt} \%$, respectively. 


\section{Amphibole}

Amphiboles in the matrix occur as distinct composite grains showing wide compositional ranges reaching from sodic, through subcalcic, to calcic amphiboles (Fig. 11, Table 2). The glaucophane core of the composite grains is weakly zoned with decreasing $\mathrm{Al}$ and increasing

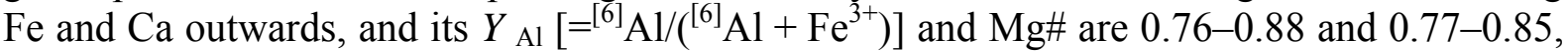
respectively (Fig. 11b). The winchite/barroisite mantle mostly shows compositional ranges of $\mathrm{Si}=7.31-7.73$ per formula unit (pfu), ${ }^{[\mathrm{B}]} \mathrm{Na}=0.72-1.03$ pfu and ${ }^{[\mathrm{A}]}(\mathrm{Na}+\mathrm{K})=0.12-0.34$ pfu. Si-poor amphiboles that occur at the outermost rim of the composite amphibole (Fig. 4d) and the interface between garnet and barroisite (Fig. $\underline{5}$ ) have $\mathrm{Si}=6.05-7.08 \mathrm{pfu},{ }^{[\mathrm{B}]} \mathrm{Na}=0.42-$ $1.01 \mathrm{pfu}$ and ${ }^{[\mathrm{A}]}(\mathrm{Na}+\mathrm{K})=0.44-0.86 \mathrm{pfu}$. Later stage amphiboles after garnet and omphacite show distinct compositional ranges of pargasite $\left[\mathrm{Si}=5.85-6.29 \mathrm{pfu},{ }^{[\mathrm{B}]} \mathrm{Na}=0.27-0.42 \mathrm{pfu}\right.$ and $\left.{ }^{[\mathrm{A}]}(\mathrm{Na}+\mathrm{K})=0.81-0.94 \mathrm{pfu}\right]$ and barroisite/edenite $\left[\mathrm{Si}=6.14-6.96 \mathrm{pfu},{ }^{[\mathrm{B}]} \mathrm{Na}=0.45-\right.$ $1.01 \mathrm{pfu}$ and $\left.{ }^{[\mathrm{A}]}(\mathrm{Na}+\mathrm{K})=0.44-0.86 \mathrm{pfu}\right]$, respectively.

Amphiboles included in garnet are compositionally variable from barroisite/katophorite to taramite. They are grouped into Si-rich $(\mathrm{Si}>7.1 \mathrm{pfu})$ and $\mathrm{Si}$-poor $(\mathrm{Si}<7.1 \mathrm{pfu})$ phases on the basis of composition and texture. The former-type inclusions are relatively large grains of $200-300 \mu \mathrm{m}$ in length and have limited compositional ranges of $\mathrm{Si}=7.12-7.39 \mathrm{pfu}$, ${ }^{[\mathrm{B}]} \mathrm{Na}=0.83-0.96 \mathrm{pfu}$ and ${ }^{[\mathrm{A}]}(\mathrm{Na}+\mathrm{K})=0.17-0.28$ pfu. The Si-rich inclusions show similar $\mathrm{Si},{ }^{[\mathrm{B}]} \mathrm{Na}$ and ${ }^{[\mathrm{A}]}(\mathrm{Na}+\mathrm{K})$ contents to barroisitic mantle of matrix amphiboles, and their $\mathrm{Mg \#}$ $(0.63-0.74)$ is distinctly lower than that of the matrix barroisite $(0.68-0.86)$. The Si-poor inclusions occur as small grains of $10-30 \mu \mathrm{m}$ in diameter and have scattered compositional ranges of $\mathrm{Si}=6.09-7.04 \mathrm{pfu},{ }^{[\mathrm{B}]} \mathrm{Na}=0.43-1.02 \mathrm{pfu}$ and ${ }^{[\mathrm{A}]}(\mathrm{Na}+\mathrm{K})=0.34-0.78 \mathrm{pfu}$ which are similar to those of the Si-poor outermost rim of zoned matrix amphibole. Such a Si-poor amphibole also occurs as rims around the Si-rich large inclusions. Cracks commonly develop in the host garnet around amphibole inclusions. Thus (1) the Si-poor parts of amphibole inclusions are interpreted as those recrystallizing coevally with the formation stage of matrix katophorite/edenite/taramite, and (2) the Si-rich barroisitic cores of large inclusions possibly preserve amphibole compositions of the prograde stage.

\section{Epidote}

$Y_{\mathrm{Fe}}\left[=\mathrm{Fe}^{3+} /\left(\mathrm{Fe}^{3+}+\mathrm{Al}+\mathrm{Cr}\right)\right]$ of epidote included in garnet is variable from 0.19 to $0.30(0.24$ in average). The matrix epidote is slightly Al-richer $\left(Y_{\mathrm{Fe}}=0.18-0.26\right.$ and 0.21 in average $)$ than the inclusion epidote (Table 1$)$. The vein epidote is distinctly Al-poorer $(0.35-0.36)$ than other epidotes.

\section{Metamorphic evolution of the eclogitic xenolith}

The eclogite xenolith well preserves the textural and compositional characteristics suggesting reaction relations of minerals and a $P-T$ path during HP metamorphism. Table $\underline{3}$ summarizes the evolution of mineral parageneses during the prograde and retrograde evolution stages which are related to subduction and exhumation, respectively.

\section{Subduction stage}

The zonal structure of garnet with increasing $X_{\text {prp }}$ and decreasing $X_{\text {sps }}$ from core to rim may suggest a prograde formation of garnet (Fig. 7). The garnet core includes epidote, chlorite and 
barroisite, and the $\mathrm{Mg}$-rich and Ca-poor mantle characteristically contains omphacite inclusions. The garnet mantle contains rare inclusions (see Fig. 7), and it is difficult to identify stable amphibole during the garnet mantle formation. The comparison between amphibole included in garnet core and zoned amphibole in the matrix, however, implies that sodic amphibole was possibly stable during the later stages of garnet crystallization. These facts suggest that during garnet formation metamorphic conditions shifted from the high-P greenschist/low-P blueschist facies to blueschist/low-T eclogite facies, and the assemblage of garnet + omphacite + glaucophane + rutile + epidote + quartz was stable at later subduction stage and/or peak metamorphic stages. The compositional change of amphibole from winchite/barroisite to glaucophane during prograde stage is well documented in glaucophaneeclogites from some HP metamorphic belts such as the Western Norway (Krogh 1980), NW Himalaya (de Sigoyer et al. 1997) and Sanbagawa (Aoya et al. 2003). The Sanbagawa example has recorded a very steep subduction-stage $P-T$ path with $\mathrm{d} P / \mathrm{d} T>0.7 \mathrm{GPa} / 100^{\circ} \mathrm{C}$ (Aoya et al. 2003).

Temperature conditions were estimated using the garnet-clinopyroxene $\mathrm{Fe}-\mathrm{Mg}$ geothermometer as following Powell (1985), Krogh Ravna (2000), Nakamura and Hirajima (2005), and Ellis and Green (1979) calibrations with activity models of Holland (1990) for clinopyroxene and of Berman and Aranovich (1996), Ganguly et al. (1996) and Mukhopadhyay et al. (1997) for garnet. The calculated $T$ conditions range from 415 to $515^{\circ} \mathrm{C}$ at $P=1.5 \mathrm{GPa}$ for average compositions of garnet outermost rim and jadeite-rich parts of omphacite $\left(X_{\mathrm{jd}}=0.4\right)$ depending on the employed calibrations. Coexisting glaucophane, epidote, omphacite and quartz other than garnet were stable at the peak metamorphic stage, and thus the minimum and maximum pressure conditions of this stage can be defined by the following reactions, respectively:

\author{
albite $=$ jadeite + quartz $($ Holland 1980) \\ and \\ omphacite + lawsonite $=$ clinozoisite + glaucophane + quartz $+\mathrm{H}_{2} \mathrm{O}($ Evans 1990 ; \\ Miyazaki et al. 1996).
}

The assemblages of the right-hand sides for these two reactions were stable at the peak metamorphic stage. Thus the minimum and maximum pressure conditions are estimated at 1.1 and $1.9 \mathrm{GPa}$ at $T=500^{\circ} \mathrm{C}$, respectively, for the average compositions of glaucophane, matrix epidote $\left(Y_{\mathrm{Fe}}=0.21\right)$ and jadeite-rich parts of omphacite using Thermocalc 3.2 and AX2.2 (Holland and Powell 1998). The combinations of the garnet-clinopyroxene $\mathrm{Fe}-\mathrm{Mg}$ geothermometer and these net transfer reactions give possible $P-T$ ranges of $0.9-2.1 \mathrm{GPa}$ and $400-530^{\circ} \mathrm{C}$ (Fig. 12) for the peak subduction stage, which is consistent with the stability field of a glaucophane + epidote + quartz $+\mathrm{H}_{2} \mathrm{O}$ assemblage simulated for an idealized basaltic system (Evans 1990).

\title{
Exhumation stage
}

The compositional evolution of amphibole during exhumation is summarized as glaucophane $\rightarrow$ winchite/barroisite $\rightarrow$ katophorite/edenite/taramite. The initial replacements of glaucophane by subcalcic amphibole are frequently described for HP metamorphic rocks suggesting a lower $P / T$ eclogite, epidote-amphibolite and/or higher-P greenschist facies overprint during exhumation (e.g. Krogh 1980; de Sigoyer et al. 1997; Matsumoto et al. 2003; Ota et al. 2004). This replacement was possibly related to the reaction: 
glaucophane + jadeite + garnet + quartz $+\mathrm{H}_{2} \mathrm{O}=$ barroisite (Ota et al. 2004).

Thin bands of katophorite and less silicic amphiboles occur (1) around winchite/barroisite composite grains (Fig. 4), (2) at the interface between garnet and barroisite and (3) in veins (Fig. 5). These amphiboles are distinctly richer in Ca-tschermakite and edenite components than winchite/barroisite formed at the earlier stage of exhumation. This mineralogical succession suggests that the studied sample has experienced a relatively high temperature metamorphic event under epidote-amphibolite and/or amphibolite facies conditions at the latest stage of exhumation. Pargasite pseudomorphs after garnet also show a similar event. It seems that this process can be compared to that of the eclogitic xenoliths described in the ultramafic Raobazai complex of the Central Dabieshan Domain. Thus, reequilibrium under the epidote-amphibolite or higher-grade conditions were overprinted on these eclogites during the late phase of metamorphism (Tsai and Liou 2000; Xiao et al. 2001; Fig. 1).

\section{Chronological constraints}

Several metamorphic and magmatic samples from the Central Dabieshan Domain were collected in order to place age constraints on the tectono-metamorphic and cooling evolution of the rocks. These samples, located in Fig. 1, include two granites (samples DB122 and DB 135) and a decameter-sized marble restite in the non-foliated migmatite (DB121), which crops out near the Mesozoic granite. The sample DB 135 is a biotite-hornblende granite which encloses the above studied eclogite xenolith. Earlier $\mathrm{U} / \mathrm{Pb}$ and $\mathrm{Rb} / \mathrm{Sr}$ dating on primary magmatic titanite and biotite from a felsic part of granodiorite, such as that shown in the photograph of Fig. 3, were undertaken to confirm the timing of the granite formation (Faure et al. 2003). The five identical titanite $\mathrm{U} / \mathrm{Pb}$ analyses yielded a mean age of $118.1 \pm 1.9(2 \sigma) \mathrm{Ma}$ and six biotite $+\mathrm{K}$-feldspar fractions define a $\mathrm{Rb} / \mathrm{Sr}$ isochron age of $102.4 \pm 2.2(2 \sigma) \mathrm{Ma}$, yielding a $\mathrm{Sr}_{\mathrm{i}}$ of $0.70684 \pm 0.00003$.

The samples of DB121 DB122 were selected for ${ }^{40} \mathrm{Ar} /{ }^{39} \mathrm{Ar}$ population dating. Whole rocks were crushed, sieved and individual grains of biotite, muscovite and amphibole were chosen under binoculars. All separates were irradiated, in a single irradiation, at the Ford Nuclear reactor at the University of Michigan in position L 67 . The analytical device and procedures used in the ${ }^{40} \mathrm{Ar} /{ }^{39} \mathrm{Ar}$ laboratory of the University of Blaise Pascal of Clermont-Ferrand are similar to that described in Faure et al. (2003). The age spectra are shown in Fig. 13.

Cretaceous ages have been obtained whether the analyzed minerals come from the pluton or from the marble restite in the migmatite. In most cases, the good plateaus suggest geologically significant ages. The ages from 109 to 112 Ma seem significant with amphiboles (DB122) and muscovite (DB121) (Fig. 13) but the inverse isochrons suggest that excess argon may be present in both of those samples, suggesting younger ages of ca. $106 \mathrm{Ma}$, thus tightening the cluster of ages. Finally, the DB122 biotite spectrum appears highly scattered and geologically meaningless. This is probably an effect of partial alteration rather than a thermal loss, as suggested in the complex but correlated $\mathrm{K} / \mathrm{Ca}$ pattern (Fig. 13). Analytical data are represented in Table 4. 


\section{Discussion}

\section{Metamorphic $\boldsymbol{P}-\boldsymbol{T}$ conditions/thermobarometric constraints}

Petrological results show that the eclogite xenolith had recorded a wide spectrum of metamorphic conditions that comply with subduction and exhumation processes. The prograde formation of garnet and its inclusions (Figs. 7, 8) show the prograde metamorphism corresponding to subduction process (Fig. 12). The peak metamorphic stage is estimated at 0.9-2.1 GPa and $390-530^{\circ} \mathrm{C}$ by mineral composition. The progressive evolution from glaucophane $\rightarrow$ winchite/barroisite $\rightarrow$ katophorite/edenite/taramite indicates a subsequent reequilibrium during exhumation. The zoned amphiboles imply two possible $P-T$ paths of the eclogite xenolith as follows. The first model is a simple clockwise path involving a long thermal reequilibration under epidote-amphibolite facies or higher-grade conditions during exhumation like the south Dabieshan "cold" (HP) eclogite zone of Zhujiachong (Castelli et al. 1998) and Huangzhen (Franz et al. 2001) area. In this model, the subcalcic and calcic amphiboles around glocophane core are considered to have formed during adiabatic exhumation (Fig. 12, P-T path (1)). The second model emphasizes (1) the formations of winchite/barroisite prior to those of katophorite/edenite and less silicic amphiboles (Fig. 4), (2) the occurrences of taramite and pargasite at the interface between garnet and barroisite and as vein phase (Fig. 5), and pargasite pseudomorph after garnet. These textural and chemical characteristics of the matrix amphiboles imply a possibility that the eclogite xenolith has experienced temperature increase at later stage of exhumation (Fig. 12, $P-T$ path (2)). This interpretation is quite similar to the case of blueschist facies rocks in the Tinos Island of the Agean domain (Parra et al. 2002). We have no definite evidence to evaluate which model is appropriate for exhumation $P-T$ path of the xenolith. However, the second model of $P-T$ path is more likely, and the inferred temperature increase at the latest stage of exhumation is likely associated to the regional migmatization which is a typical feature of the Central Dabieshan Domain based on the following lines of evidence: (1) the main deformation related to exhumation occurred before the migmatization and granitization, as discussed in the following chapter and (2) the inferred temperature increase at the latest stage of exhumation is typical in the Central Dabieshan Domain, and is absent in the South Dabieshan Domain which records no evidence of migmatization (Tsai and Liou 2000; Xiao et al. 2001; Liu et al. 2001).

Through the detailed analysis of the eclogite xenolith in the Mesozoic granite, we can describe a possible metamorphic trajectory consisting of relatively steep subduction stage $P-T$ path followed by a relatively high temperature metamorphic event at the latest stage of exhumation. This allows us to propose a comprehensive tectonic evolution of Central Dabieshan Domain.

\section{Thermal history of the gneiss dome in Central Dabieshan Domain}

Since titanite is a primary magmatic phase in the felsic granitic rocks, the $118.1 \pm 1.9 \mathrm{Ma}$ age can be interpreted to date crystallisation of the felsic magma, whereas the $\mathrm{Rb} / \mathrm{Sr}$ age of $102.4 \pm 2.2 \mathrm{Ma}$ dates the time at which the solid rock cooled below $250^{\circ} \mathrm{C}$. $\mathrm{The}^{\mathrm{S}} \mathrm{Sr}_{\mathrm{i}}$ of 0.7068 defined by the K-feldspar-biotite isochron indicates that the protolith gneisses were derived either from crustal material having a few hundred million years of crustal residence time or by the mixing of mantle melts with crust of much older, possibly Paleoproterozoic in age. Given the fact that the ${ }^{40} \mathrm{Ar} /{ }^{39} \mathrm{Ar}$ ages free of excess ${ }^{40} \mathrm{Ar}$ lie between the $118 \mathrm{Ma} \mathrm{U} / \mathrm{Pb}$ and $102 \mathrm{Ma}$ $\mathrm{Rb} / \mathrm{Sr}$ ages, simple cooling during exhumation seems to be the most plausible explanation for 
the age spectra. This is also consistent with the general assumption that Ar closure temperatures for amphiboles and white micas lie between roughly 530 and $300^{\circ} \mathrm{C}$, being higher than that of $\mathrm{Rb} / \mathrm{Sr}$ closure at $\approx 250^{\circ} \mathrm{C}$ in biotite, yielding actually the youngest age (Harrison 1981; Dahl 1996). Given the entire set of Cretaceous ages from Central Dabieshan Domain (Fig. 1), the $118 \mathrm{Ma}$ age for granite is significantly younger than 135-126 Ma zircon ages determined for the emplacement of gabbroic to granitic bodies within the gneissic part of the dome (Hacker et al. 1996, 1998; Xue et al. 1997; Xiao et al. 2001). Early intrusions (135$130 \mathrm{Ma}$ ) are deformed, whereas younger bodies such as our $118 \mathrm{Ma}$ granodioritic pluton exhibit perfectly preserved and undeformed magmatic mineral assemblages, strengthening the view that intrusion occurred essentially after regional ductile deformation or at its very end. This confirms the structural observation that magmatism occurred prior to, as well as after, main ductile deformation, lasting for a considerable period of time, i.e., at least between 135 and $118 \mathrm{Ma}$. The presence of eclogite xenoliths in the felsic part of the granodiorite suggests that melts may have been formed in medium crustal levels, from where they migrated into the presently exposed level of country gneisses.

Figure 14 shows two different cooling stages in the thermal history of the gneiss dome derived from our dating results from Central Dabieshan Domain. To construct the path, a minimum blocking temperature of $650^{\circ} \mathrm{C}$ was used for the $\mathrm{U} / \mathrm{Pb}$ system in titanite (Zhang and Schärer 1999), $530^{\circ} \mathrm{C}$ for the $\mathrm{K}-\mathrm{Ar}$ chronometer in amphiboles (Harrison 1981; Dahl 1996), $350^{\circ} \mathrm{C}$ for muscovite (Purdy and Jäger 1976 ), and $300^{\circ} \mathrm{C}$ for $\mathrm{Rb} / \mathrm{Sr}$ in biotite yielding a smooth cooling rate of $22^{\circ} \mathrm{C}$ per million years. High temperatures in excess of minimum melting conditions of crustal rocks must have governed the thermal regime prior to $118 \mathrm{Ma}$, lasting at least from 135 to $118 \mathrm{Ma}$, to explain gabbro to granite emplacement during this period of time. The presence of gabbro plutons also shows that mantle derived basaltic magmas intruded into the gneiss complex, which is a strong argument favoring a magmatic underplating in relation to continental rifting causing migmatization and dome formation.

\section{Tectonic significance of the survival eclogite xenolith in a Cretaceous granite}

Our results show that HP metamorphic rocks extended far to the north of the present exposures of the HP-UHP metamorphic unit of Dabieshan massif. It is likely that the entire Central Dabieshan Domain experienced the HP-UHP metamorphism before migmatization and emplacement of the Mesozoic granite. As described in the petrology section, the eclogite xenoliths in the granite pluton of the Central Dabieshan Domain were strongly hydrated under the epidote-amphibolite facies and higher-metamorphic grade. This fact demonstrates that the Central Dabieshan Domain underwent an exhumation process similar to the HP-UHP metamorphic units of the South Dabieshan Domain and implies that these two domains of the Dabieshan massif have the same geodynamic background characterized by a HP or even an UHP metamorphic evolution. This conclusion is derived not only from the trajectory of the $\mathrm{P}-$ $T$ path of eclogites but also from the architecture and tectonic evolution of the Dabieshan massif (Faure et al. 2003; Lin et al. 2005a, b). 


\section{Conclusions}

The petrological and mineralogical data of the eclogite xenolith, together with the geochronological results for its host granite, indicate that the eclogite has recorded prograde and retrograde metamorphic processes during subduction and exhumation stages prior to its trapping by an ascending granitic pluton in Early Cretaceous times. We can conclude that the Central Dabieshan Domain experienced the same regional HP-UHP eclogitic metamorphism and subsequent exhumation as the Southern Dabieshan Domain. However, conversely to the Southern Domain, in the Central Dabieshan Domain, these early evolutions are almost completely erased by the crustal melting that gave rise to migmatization and granite emplacement. A tentative geodynamic model (Fig. 15) based on the above presented petrological and geochronological works of the eclogitic xenolith and our previous structural data (Faure et al. 1999, 2003) exhibits a more reasonable tectonic evolution of the Dabieshan massif:

(a) Continental subduction: According to the paleomagnetic and palaeogeographic results (Lin et al. 1985; Enkin et al. 1992), collision between the NCB and SCB occurred in the Late Permian-Early Triassic. This convergence led to the closure of the Paleo-Qinling Ocean and northward subduction of the SCB under the NCB. During the Triassic, the continental subduction between the NCB and SCB commenced (Gilder and Courtillot 1997) with the slab subduction partly descending more than $100 \mathrm{~km}$ (Xu et al. 1992; Ye et al. 2000). During the Late Triassic continental subduction, the SCB crust was sliced along the south directed thrusts (Fig. 15a, SZ and XMF) (Fig. 15a).

(b) Syn-convergence exhumation: Contemporaneous with the subduction of the SCB, the HP and UHP metamorphic rocks were steadily exhumed to the subsurface. As convergence proceeded with southward thrusting in the south part of the Dabieshan, the earlier thrust zones, such as the Xiaotian-Mozitan fault, were reworked as normal faults. This event took place between 240 and 218 Ma (Okay et al. 1993; Hacker et al. 1996; Rowley et al. 1997) (Fig. 15b).

(c) Syn-convergence exhumation and Doming: Accompanying the continental subduction, the HP and UHP metamorphic rocks exhumed to the surface and the central part of the Dabieshan massif developed a domal structure. The eclogitized continental crust widely occupied the Central and South Domain. During the exhumation, the HP and UHP eclogite experienced the regional retrograde metamorphic overprint (Fig. 15c).

(d) and (e) Migmatization and plutonism: This final architecture of the Dabieshan massif was completed during the Cretaceous extensional event. Some of the older ductile low-angle normal faults (e.g., Xiaotian-Mozitan and Shangma faults, Fig. 1) were reworked under brittle conditions to form the border faults of half-grabens filled by continental red beds. At the same time, a huge mass of migmatite developed in the Central Dabieshan Domain (Fig. 15d). Crustal melting, possibly assisted by fluid circulations, dominantly took place at the expense of Al-rich rocks such as orthogneiss and their metasedimentary host-rocks (Fig. 15d, e).

The emplacement of the granodioritic plutons corresponds to the well-known Yanshanian event in Eastern China (Fig. 15e). The widespread development of syntectonic plutons, lava flows, extensional graben or half graben continental basins and more rarely, metamorphic core complexes in many parts of the Eastern margin of Eurasia is interpreted as due to a largescale continental extension (e.g., Ren et al. 2002; Meng et al. 2003 and enclosed references). Although very important in the building of the eastern margin of the Eurasian continent, the geodynamic setting of this world-class magmatic province is not well understood yet. However, it might explain the origin of heat advection and fluid transfer from mantle to lower crust, necessary to trigger the Cretaceous magmatism, crustal softening and continental break up. A detailed discussion of these models is beyond the scope of this paper. In the present 
state of knowledge, we consider that additional investigations are necessary in order to reach a satisfactory understanding of the geodynamic significance of the continental-scale Mesozoic extension in East Asia.

\section{Acknowledgments}

The results presented in this study are issued from the National Key Basic Research Program (Grant No. 2005CB422101) and NSFC (40202021, 40472116). JSPS is acknowledged for providing a Grant of Postdoctoral Fellowship for Foreign Researchers (14-02060 to W.L.) and Grant-in-Aid for Scientific Research (14540448 and 18340172 to M.E.). We are indebted to P. O'Brian and S. Guillot for careful review, constructive criticism, and helpful suggestions.

\section{References}

Ai Y (1994) A revision of the garnet-clinopyroxene $\mathrm{Fe}^{2+}-\mathrm{Mg}$ exchange geothermometer. Contrib Miner Petrol 115:467-473

Aoya M, Uehara S, Matsumoto M, Walli SR, Enami M (2003) Subduction-stage pressuretemperature path of eclogite from the Sambagawa Belt; prophetic record for oceanic-ridge subduction. Geology 31:1045-1048

Berman RG, Aranovich LY (1996) Optimized standard state and solution properties of minerals; I, Model calibration for olivine, orthopyroxene, cordierite, garnet, and ilmenite in the system $\mathrm{FeO}-\mathrm{MgO}-\mathrm{CaO}-\mathrm{Al}_{2} \mathrm{O}_{3}-\mathrm{TiO}_{2}-\mathrm{SiO}_{2}$. Contrib Miner Petrol 126:1-24

BGMR-Anhui, Bureau of Geology and Mineral Resources (1987) Regional geology of Anhui Province. Geol Mem, Geol Pub House, Beijing, Vol. 5, pp 1-721

BGMR-Hubei, Bureau of Geology and Mineral Resources (1990) Regional geology of Hubei Province. Geol Mem, Geol Pub House, Beijing, Vol. 20, pp 1-705

Carswell DA (1990) Eclogite and the eclogite facies: definitions and classification. In: Carswell DA (ed) Eclogite facies rocks. Blackie, Glasgow, pp 1-13

Castelli D, Rolfo F, Compagnoni R, Xu S (1998) Metamorphic veins with kyanite and quartz in the Zhu-Jia-Chong, Dabie Shan, China. Isl Arc 7:159-173

Coleman RG, Wang X (1995) Overview of the Geology and tectonics of UHPM. In: Coleman RG, Wang $\mathrm{X}$ (eds) Ultrahigh pressure metamorphism. Cambridge University Press, Cambridge, pp. 1-32

Coleman RG, Lee DE, Beatty LB, Brannock WW (1965) Eclogites and eclogites; their differences and similarities. Geol Soc Am Bull 76:483-508

Cong B, Wang Q (1994) Review of UHP rocks in China. Chin Sci Bull 39:2214-2218

Cong B, Wang Q (1996) A review on research of UHPM rocks in the Dabieshan-Sulu region. In: Cong B (eds) Ultrahigh-pressure metamorphic rocks in the Dabieshan-Sulu region of China. Science Press, Beijing pp. 8-26 
Cong B, Wang Q (1999) The New advantage in ultrahigh pressure metamorphic region in Dabie-Sulu Mountains. Chin Sci Bull 44:1127-1141

Dahl PS (1996) The effects of composition on retentivity of argon and oxygen in hornblende and related amphiboles: a field-tested empirical model. Cosmochim Acta 60:3687-3700

de Sigoyer J, Guillot S, Lardeaux JM, Mascle G (1997) Glaucophane-bearing eclogites in the Tso Morari Dome (eastern Ladakh, NW Himalaya). Eur J Miner 9:1073-1083

Deer WA, Howie RA, Zussman J (1997) Double-chain silicates. Rock-forming minerals, Vol. 2B. Longman, London, pp 1-764

Dong S, Gao R, Cong B, Zhao Z, Liu X, Li S, Li Q, Huang D (2004) Crustal structure of the southern Dabie ultrahigh-pressure orogen and Yangtze foreland from deep seismic reflection profiling. Terra Nova 16:319-324

Eide EA, McWilliams MO, Liou JG (1994) 40 Ar/ 39Ar geochronology and exhumation of high-pressure to ultrahigh-pressure metamorphic rocks in east-central China. Geology 22:601-604

Ellis DJ, Green DH (1979) An experimental study of the effect of Ca upon the garnet clinopyroxene $\mathrm{Fe}-\mathrm{Mg}$ exchange equilibria. Contrib Miner Petrol 71:13-22

Enkin R, Yang ZY, Chen Y, Courtillot V (1992) The Paleomagnetic constraints on the geodynamic history of the major blocks of China for the Permian to the present. J Geophys Res 97:13,953-13,989

Ernst WG, Liou JG (1999) Overview of UHP metamorphism and tectonics in well-studied collisional orogens. Int Geol Rev 41:477-493

Evans BW (1990) Phase relations of epidote-blueschists. Lithos 25:3-23

Faure M, Lin W, Scharer U, Shu L, Sun Y, Arnaud N (2003) Insight into continental subduction and exhumation of UHP rocks from structural and radiometric data of the Dabieshan (E. China). Lithos 70:213-241

Faure M, Lin W, Shu L, Sun Y (1999) Tectonics of the Dabieshan (eastern China) and possible exhumation mechanism of ultra high-pressure rocks. Terra Nova 11:251-258

Franz L, Romer RL, Klemd R, Schimd R, Oberhanshli R, Wagner T, Dong S (2001) Eclogitefacies quartz veins within metabasites of the Dabie Shan (eastern China): pressuretemperature-time-deformation path, composition of the fluid phase and fluid flow during exhumation of high-pressure rocks. Contrib Miner Petrol 141:322-346

Ganguly J, Cheng W, Tirone M (1996) Thermodynamics of aluminosilicate garnet solid solution: new experimental data, an optimized model, and thermometric applications. Contrib Miner Petrol 126:137-151 
Gilder S, Courtillot V (1997) Timing of the North-South China collision from new middle to late Mesozoic Paleomagnetic data from the North China Block. J Geophys Res 102:1771317727

Griffin WL, O'Reilly SY, Pearson NJ (1990) Eclogite stability near the crust-mantle boundary. In: Carswell DA (ed) Eclogite facies rocks. Blackie, Glasgow, pp 291-314

Hacker BR, Ratschbacher L, Webb L, Ireland T, Walker D, Suwen D (1998) U/Pb zircon ages constrain the architecture of the ultrahigh-pressure Qinling-Dabie Orogen, China. Earth Planet Sci Lett 161:215-230

Hacker BR, Wang X, Eide EA, Ratschbacher L (1996) The Qinling-Dabie ultrahigh-pressure collisional orogen. In: Yin A, Harrison TM (eds) Tectonic evolution of Asia. Cambridge University Press, Cambridge, pp 345-370

Harrison TM (1981) Diffusion of ${ }^{40} \mathrm{Ar}$ in hornblende. Contrib Miner Petrol 78:324-331

Holland TJB, Powell R (1998) An internally consistent thermodynamic data set for phases of petrological interest. J Metamorph Geol 16:309-343

Holland TJB (1990) Activities of components in omphacitic solid solutions. An application of Landau theory to mixtures. Contrib Miner Petrol 105:446-453

Holland TJB (1980) The reaction albite $=$ jadeite + quartz determined experimentally in the range $600-1200^{\circ} \mathrm{C}$. Am Miner 65:129-134

Kretz R (1983) Symbols for rock-forming minerals. Am Miner 68:277-279

Krogh Ravna E (2000) The garnet-clinopyroxene $\mathrm{Fe}^{2+}-\mathrm{Mg}$ geothermometer: an updated calibration. J Metamorph Geol 18:211-219

Krogh EJ (1980) Geochemistry and petrology of glaucophane-bearing eclogites and associated rocks from Sunnfjord, western Norway. Lithos 13:355-380

Leake BE, Woolley AR, Arps CES, Birch WD, Gilbert MC, Grice JD, Hawthorne FC, Kato A, Kisch HJ, Krivovichev VG, Linthout K, Laird J, Mandarino J, Maresch WV, Nickel EH, Schumacher JC, Smith DC, Stephenson NCN, Ungaretti L, Whittaker EJW, Youzhi G (1997) Nomenclature of amphiboles: report of the subcommittee on amphiboles of the International Mineralogical Association Commission on new minerals and mineral names. Miner Mag 61:295-321

Lin JL, Fuller M, Zhang WY (1985) Preliminary Phanerozoic polar wander paths for the North and South China Blocks. Nature 313:444-449

Lin W, Wang QC, Shi Y (2005a) Architecture, kinematics and deformation analysis in DabieSulu collision zone. Acta Petrol Sin 21:1195-1214

Lin W, Faure M, Wang QC, Arnaud N (2005b) Tectonic evolution of Dabie Orogeny, in the view from polyphase deformation of Beihuaiyang Metamorphic zone. Sci China (D) 48:886899 
Liu Y, Xu S, Li S, Jiang L, Chen G, Wu W (2001) Tectonic setting and cooling history of eclogites from Northern Dabie Mountains. Earth Sci J China Univ Geosci 28:11-16

Matsumoto M, Wallis S, Aoya M, Enami M, Kawano J, Seto Y, Shimobayashi N (2003) Petrological constraints on the formation conditions and retrograde $P-T$ path of the Kotsu eclogite unit, central Shikoku. J Metamorph Geol 21:363-376

Mattauer M, Matte P, Maluski H, Xu Z, Zhang QW, Wang YM (1991) Paleozoic and Triassic plate boundary between North and South China: new structural and radiometric data on the Dabie-shan, eastern China. C R Acad Sci Ser II 312:1227-1233

Meng Q, Hu J, Jin J, Zhang Y, Xu D (2003) Tectonics of the late Mesozoic wide extensional basin system in the China-Mongolia border region. Basin Res 15:397-415

Miyashiro A (1994) Metamorphic petrology. UCL Press, London pp 1-404

Miyazaki K, Zulkarnain I, Sopaheluwakan J, Wakita K (1996) Pressure-temperature conditions and retrograde paths of eclogites, garnet-glaucophane rocks and schists from South Sulawesi, Indonesia. J Metamorph Geol 14:549-563

Mukhopadhyay B, Holdaway MJ, Koziol AM (1997) A statistical model of thermodynamic mixing properties of $\mathrm{Ca}-\mathrm{Mg}-\mathrm{Fe}^{2+}$ garnets. Am Miner 82:165-181

Nakamura D, Hirajima T (2005) Experimental evaluation of garnet-clinopyroxene thermometry as applied to eclogites. Contrib Miner Petrol 150:581-588

Nixon PH (eds) (1987) Mantle xenoliths. Wiley, New York, pp 1-844

Okay AI, Sengör AMC, Satir M (1993) Tectonics of an ultrahigh-pressure metamorphic terrane: the Dabie Shan/Tongbai shan orogen, China. Tectonics 12:1320-1334

Okay AI, Sengör AMC (1992) Evidence for intracontinental thrust related exhumation of the ultrahigh-pressure rocks in China. Geology 20:411-414

Ota T, Terabayashi M, Katayama I (2004) Thermobaric structure and metamorphic evolution of the Iratsu eclogite body in the Sanbagawa belt, central Shikoku, Japan. Lithos 73:95-126

Parra T, Vida 1O, Jolivet L (2002) Relation between the intensity of deformation and retrogression in blueschist metapelites of Tinos Island (Greece) evidenced by chlorite-mica local equilibria. Lithos 63:41-66

Peacock SM (1993) The importance of the blueschist $\rightarrow$ eclogite dehydration reactions in subducting oceanic crust. Geol Soc Am Bull 105:684-694

Powell R (1985) Regression diagnostics and robust regression in geothermometer/geobarometer calibration: the garnet-clinopyroxene geothermometer revisited. J Metamorph Geol 3:231-243 
Purdy JW, Jäger E (1976) K-Ar ages on rock-forming minerals from the Central Alps. Mem Inst Geol Min Univ Padova 30:1-34

Ren J, Kensaku T, Li S, Zhang J (2002) Late Mesozoic and Cenozoic rifting and its dynamic setting in Eastern China and adjacent areas. Tectonophysics 344:175-205

Rowley DB, Xue F, Tucker RD, Peng ZX, Baker J, Daveis A (1997) Ages of Ultrahigh Pressure Metamorphism and Protolith Orthogneisses form the Eastern Dabieshan: U/Pb Zircon Geochronology. Earth Planet Sci Lett 151:191-203

Tsai Ch, Liou JG (2000) Eclogite-facies relics and inferred ultrahigh-pressure metamorphism in the North Dabie Complex, central-eastern China. Am Miner 85:1-8

Wang X, Liou JG (1991) Regional ultrahigh-pressure coesite-bearing eclogite terrane in central China: evidence from country rocks, gneiss, marble and metapelite. Geology 19:933936

Xiao YL, Hoefs J, Van Den Kerkhof AM, Li SG (2001) Geochemical constraints of the eclogite and granulite facies metamorphism as recognized in the Raobazhai complex from North Dabieshan, China. J Metamorph Geol 18:3-19

Xu S, Liu Y, Jiang L, Su W, Ji S (1994) Tectonic regime and evolution of Dabie Mountains. Science Press, Beijing pp 1-175

Xu ST, Okay A, Ji S, Sengör AMC, Su W, Liu Y, Jiang L (1992) Diamond from Dabie Shan metamorphic rocks and its implication for tectonic setting. Science 256:80-82

Xue F, Rowley DB, Tucker RD, Peng Zh (1997) U-Pb zircon ages of granitoids rocks in the North Dabie Complex, eastern Dabie Shan, China. J Geol 105:744-753

Ye K, Cong B, Ye D (2000) The possible subduction of continental material to depths greater than $200 \mathrm{~km}$. Nature 407:734-736

Yuan XC, Klemperer SL, Teng WB, Liu LX, Chetwin E (2003) Crustal structure and exhumation of the Dabie Shan ultrahigh-pressure orogen, eastern China, from seismic reflection profiling. Geology 31:435-438

Zhai M, Cong B, Zhang Q, Wang Q (1994) The northern Dabieshan terrain: a possible Andean-type arc. Int Geol Rev 36:867-883

Zhang LS, Schärer U (1999) Age and origin of magmatism along the Cenozoic Red River shear belt, China. Contrib Miner Petrol 134:67-85

Zhang RY, Liou JG, Tsai CH (1996) Petrogeneses of a high temperature metamorphic terrane: a new tectonic interpretation for the north Dabieshan, Central China. J Metamorph Geol 14:319-333 


\section{Figures}

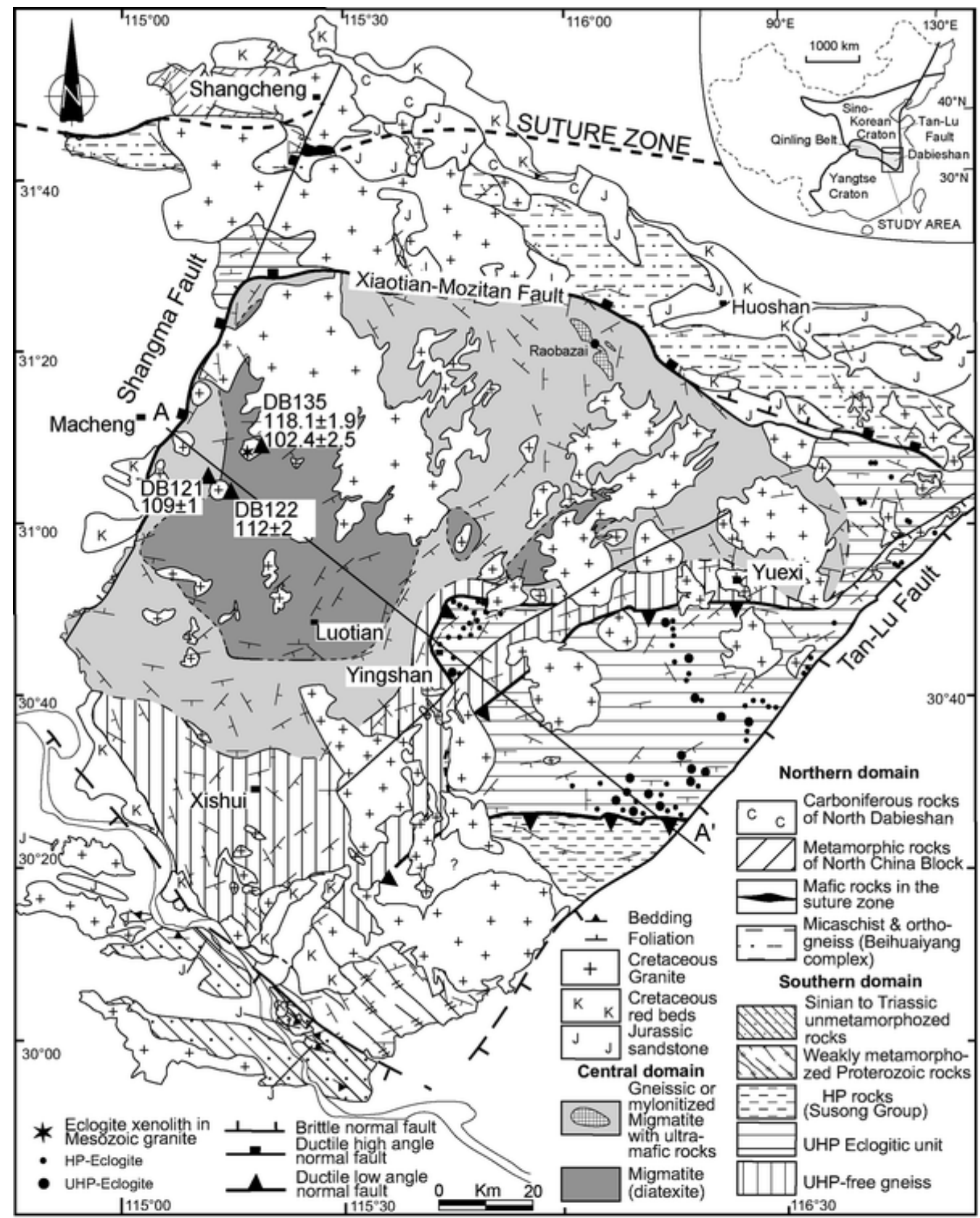

Fig. 1 Structural geological map of the Dabieshan (modified from Faure et al. 1999) 


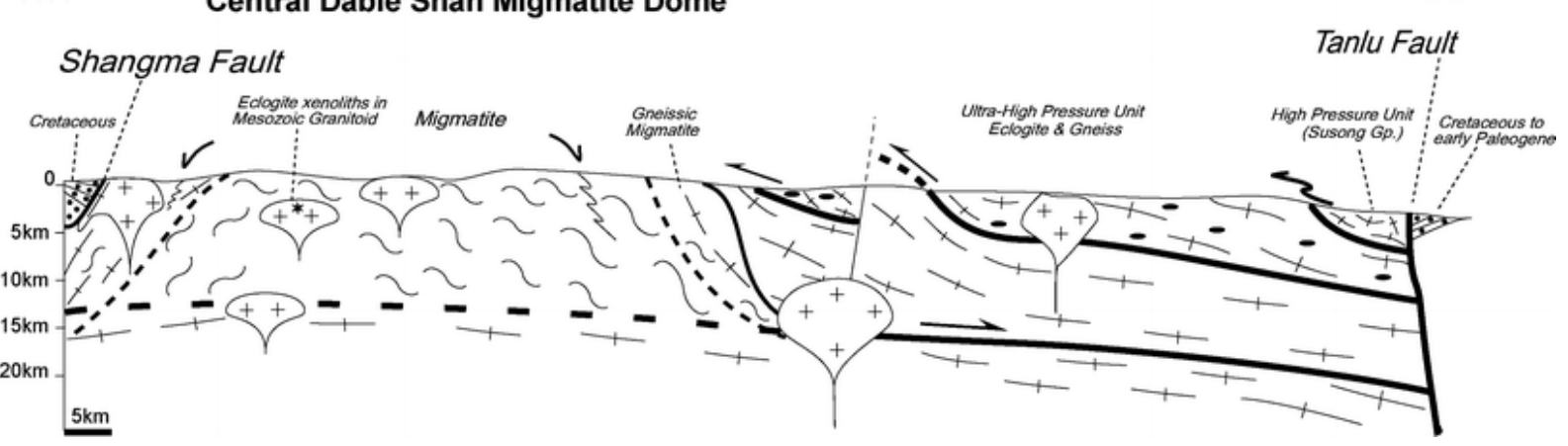

Fig. 2 Crustal scale cross-section of the Dabieshan parallel with the direction of regional kinematics
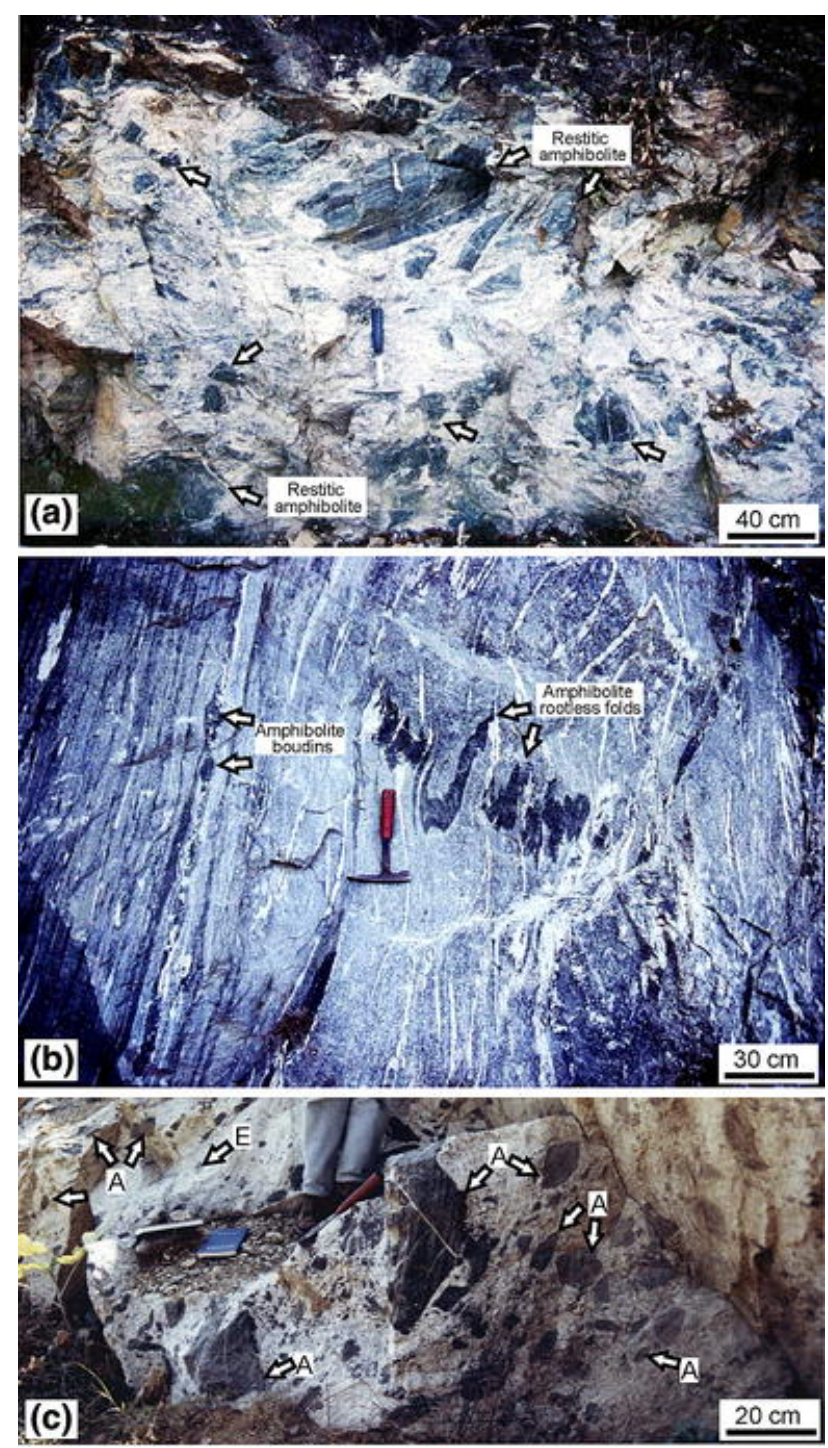

Fig. 3 Field-scale photographs. a Diatectic migmatite with restitic amphibolite, note the desultory arrangement of the amphibolite (North of Luotian city). The arrows show the restitic amphibolite; $\mathbf{b}$ Gneissic migmatite with restitic amphibolite, amphibolite oriented as boudins and rootless folds (South of Luotian city); $\mathbf{c}$ Eclogite and amphibolite xenoliths in the Cretaceous granodiorite of Central Dabieshan Domain, $E$ eclogite, $A$ amphibolite (West of Macheng city) 


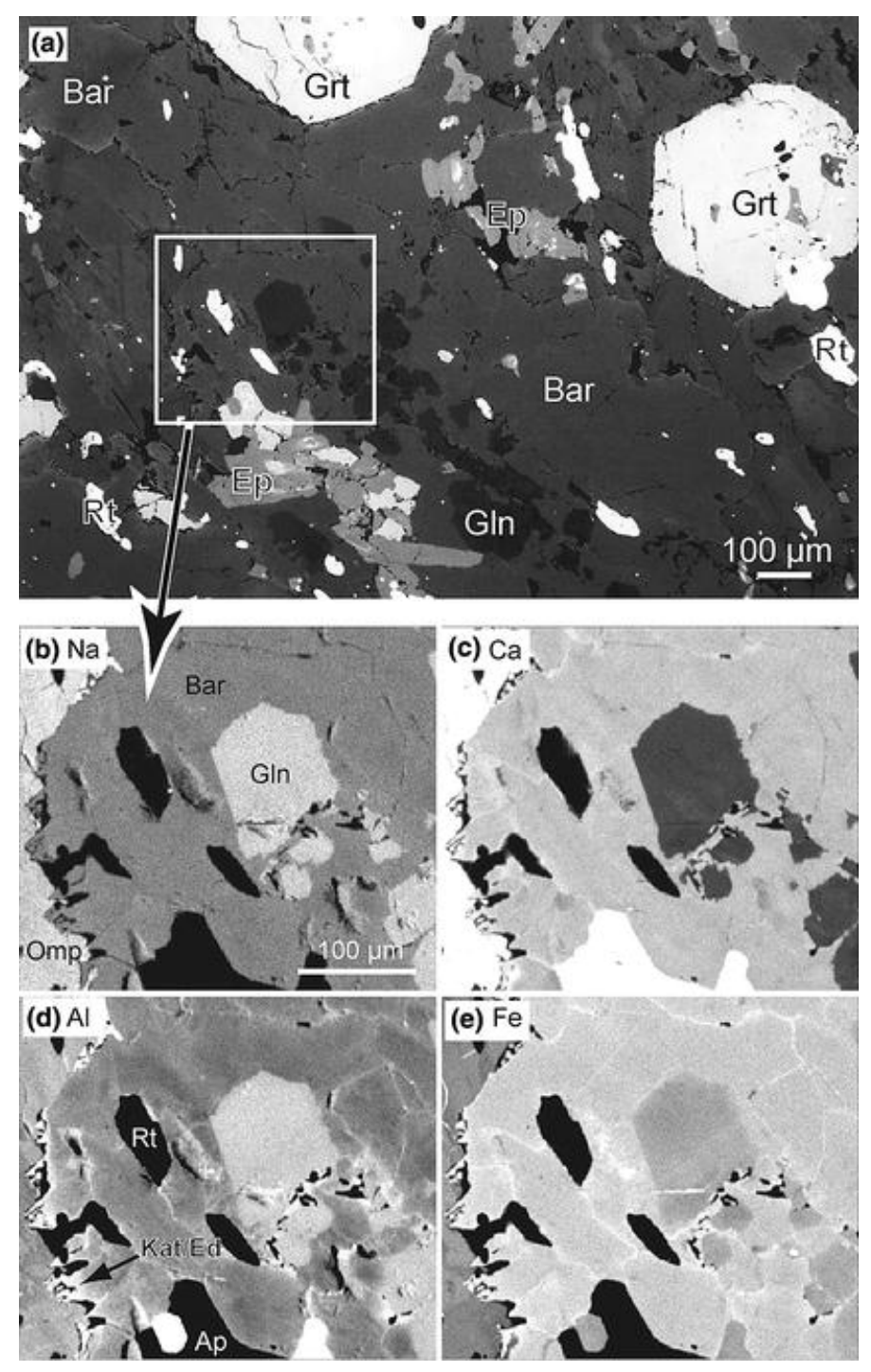

Fig. 4 Textural relationships of major phases in an eclogite xenolith from the Central Dabieshan Domain. a Back-scattered electron image showing the textural relationships among major constituent minerals. b NaKa, c $\mathrm{CaK} \alpha$, d AlK $\alpha$ and e FeK $\alpha$ X-ray mapping images of zoned glaucophane-barroisite-katophorite grain. Brighter shades indicate higher concentrations of element 


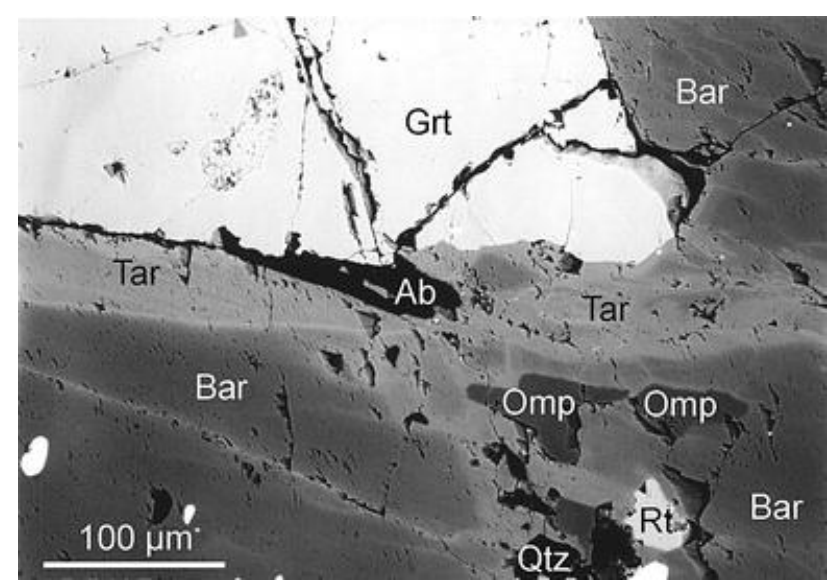

Fig. 5 Back-scattered electron image showing textural relationship between barroisite and taramite in an eclogite xenolith from the Central Dabieshan. Taramite occurs as film at interface between garnet and barroisite and as vein phase

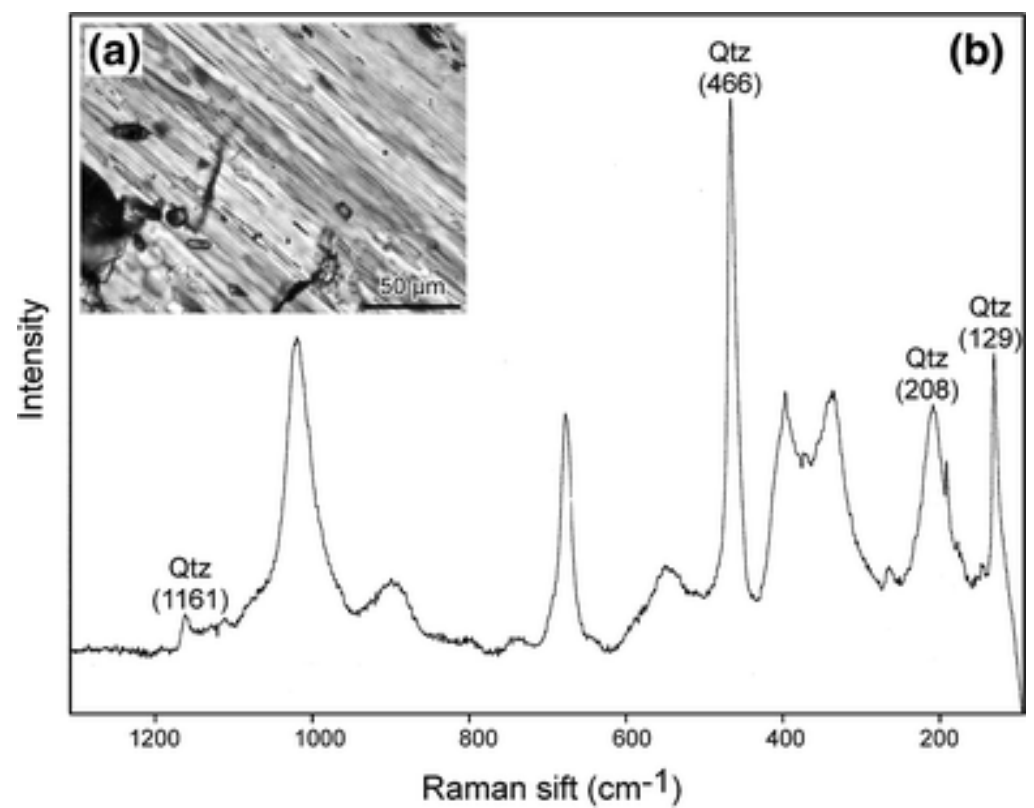

Fig. 6 a Photomicrograph of omphacite containing needle-like lamellae of quartz and $\mathbf{b}$ Raman spectrum of the quartz lamellae in an eclogite xenolith from the Central Dabieshan Domain. Number in parenthesis indicates major Raman shift of quartz 

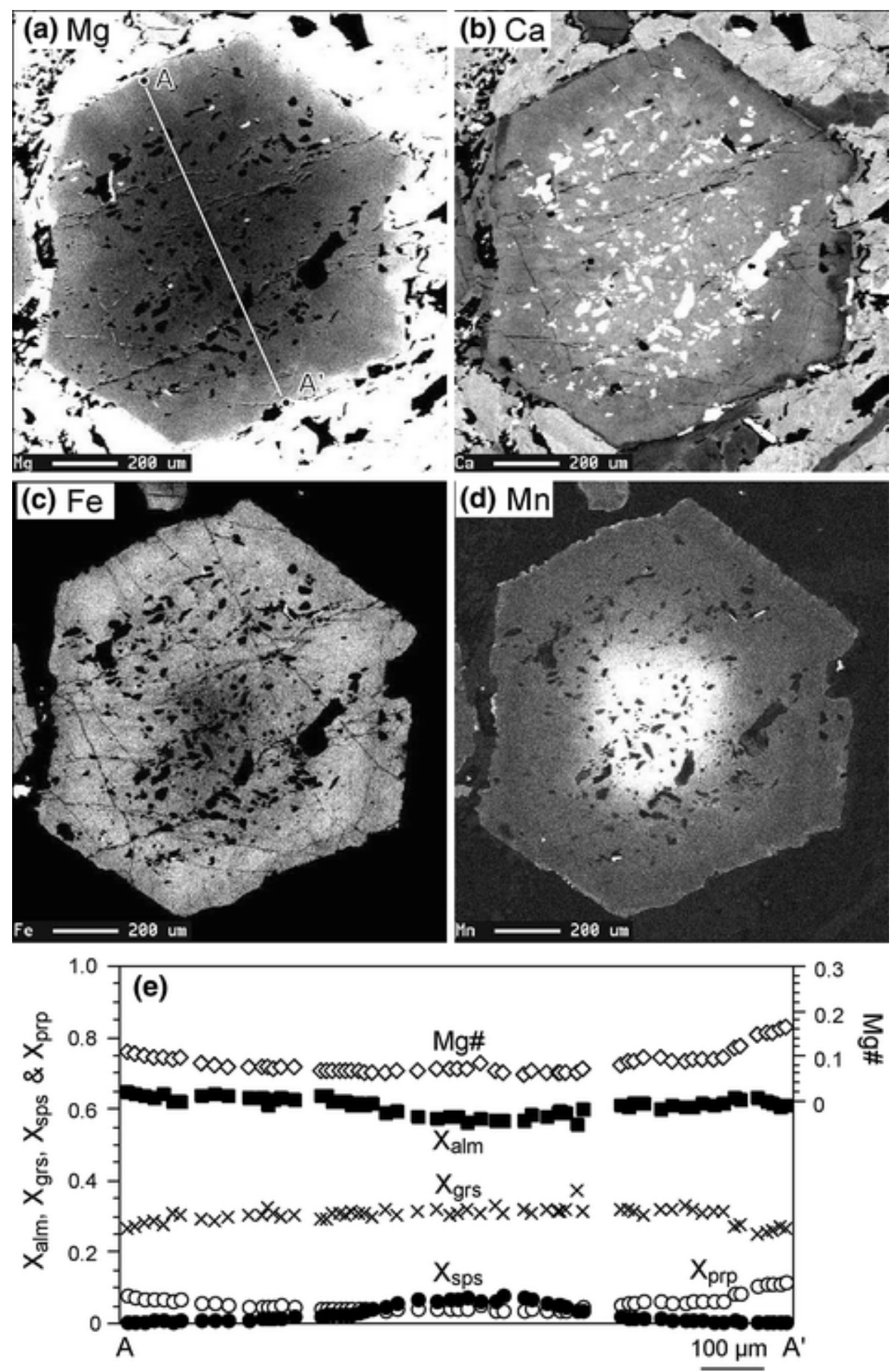

Fig. 7 a MgK $\alpha$, b $\mathrm{CaK} \alpha, \mathbf{c} \mathrm{FeK} \alpha$ and $\mathbf{d} \mathrm{MnK} \alpha$ ? X-ray mapping images and e step scanning analyses of euhedral garnet in an eclogite xenolith from the Central Dabieshan Domain. Brighter shades indicate higher concentrations of element 


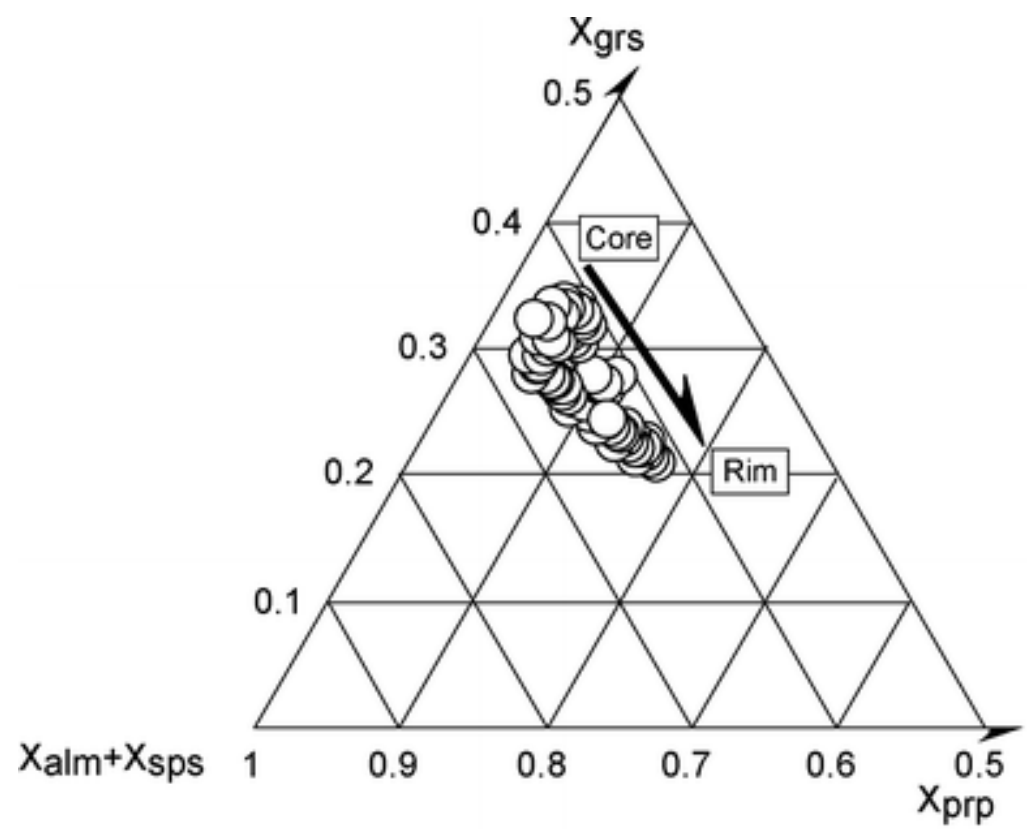

Fig. 8 Chemical composition of garnet in an eclogite xenolith from the Central Dabieshan Domain
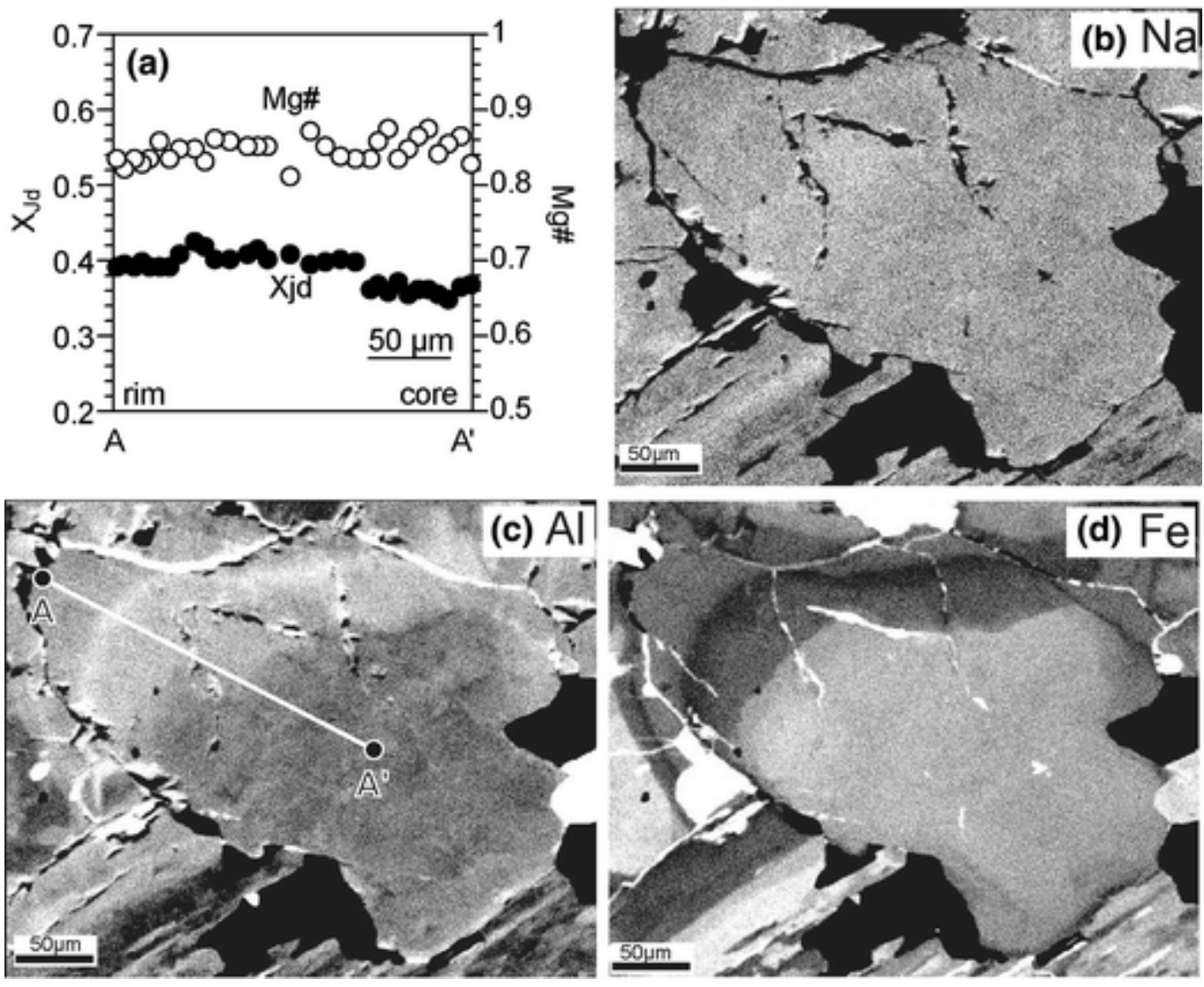

Fig. 9 a Step scanning analyses and b $\mathrm{NaK} \alpha$, c AlK $\alpha$ and d FeK $\alpha$ X-ray mapping images of zoned sodic pyroxene in an eclogite xenolith from the Central Dabieshan Domain. Brighter shades indicate higher concentrations of element 


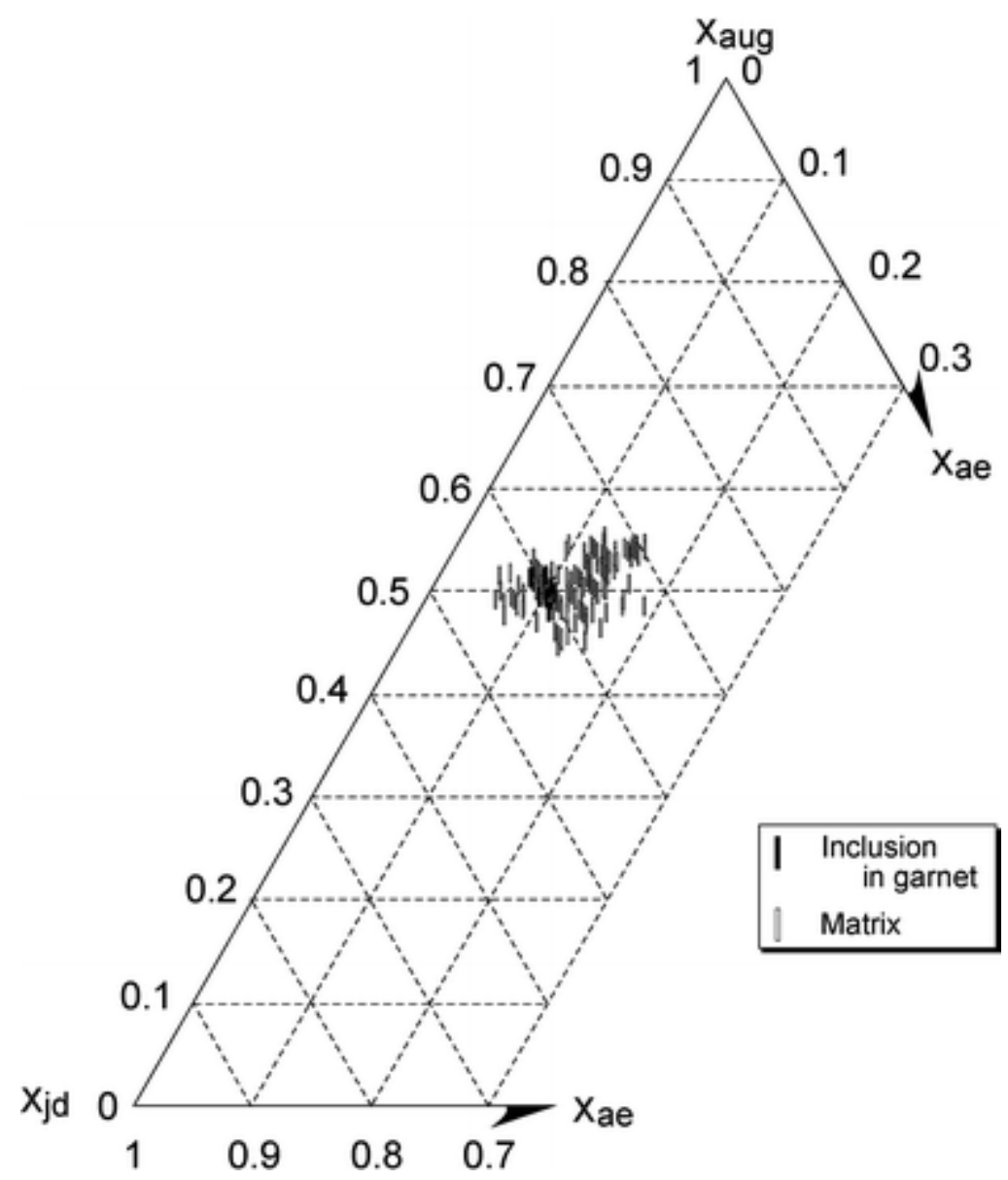

Fig. 10 Chemical compositions of sodic pyroxene in an eclogite xenolith from the Central Dabieshan Domain
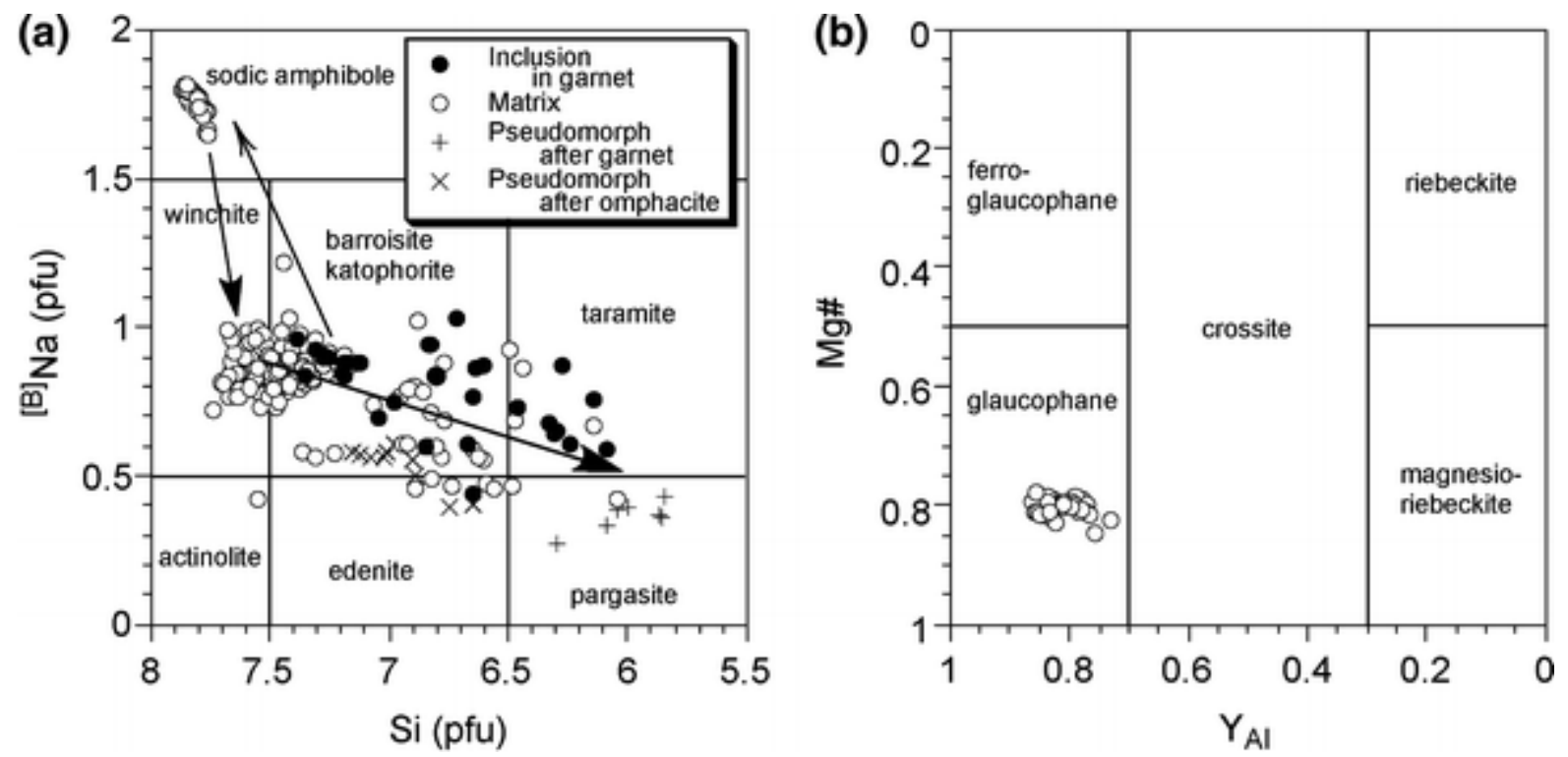

Fig. 11 a Chemical compositions of amphibole and $\mathbf{b}$ sodic amphibole in an eclogite xenolith from the Central Dabieshan Domain. Simple arrows show the prograde trajectory of the metamorphism and black arrows show the retrograde trace 


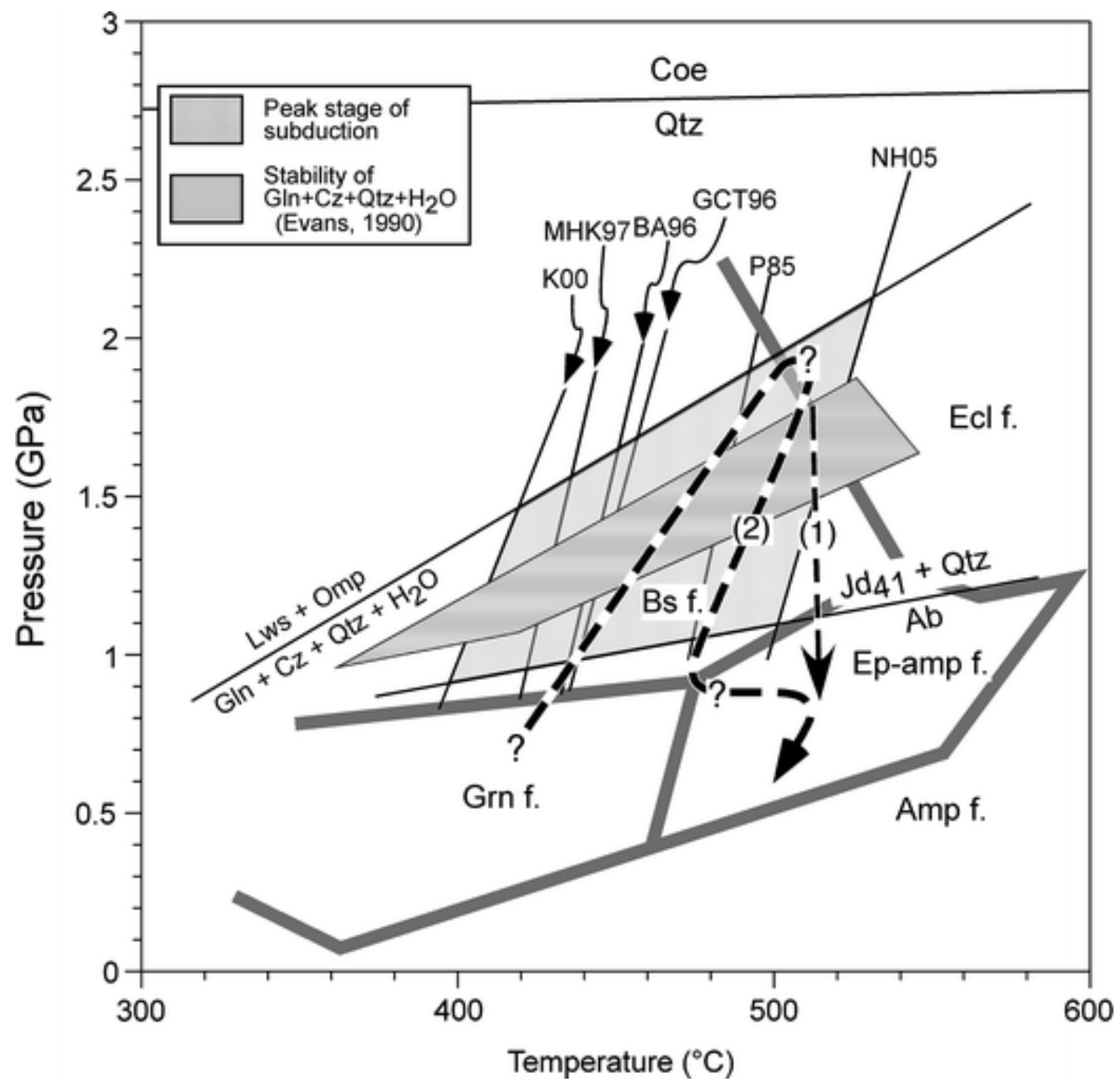

Fig. $12 P-T$ estimate for peak stage and inferred $P-T$ path recorded in an eclogite xenolith from the Central Dabieshan Domain. Garnet-clinopyroxene geothermometers: A94, Ai (1994); K00, Krogh Ravna (2000); NH05, Nakamura and Hirajima (2005); BA96, GCT96 and MHK97, Ellis and Green (1979) calibration with garnet activity models of Berman and Aranovich (1996), Ganguly et al. (1996) and Mukhopadhyay et al. (1997) for garnet, respectively (see text). Grn $f$ greenschist facies, Ep-amp $f$ epidote-amphibolite facies, Amp $f$ amphibolite facies, Bs $f$ blueschist facies, Ecl $f$ eclogite facies. Metamorphic facies boundaries are taken from Peacock (1993) 

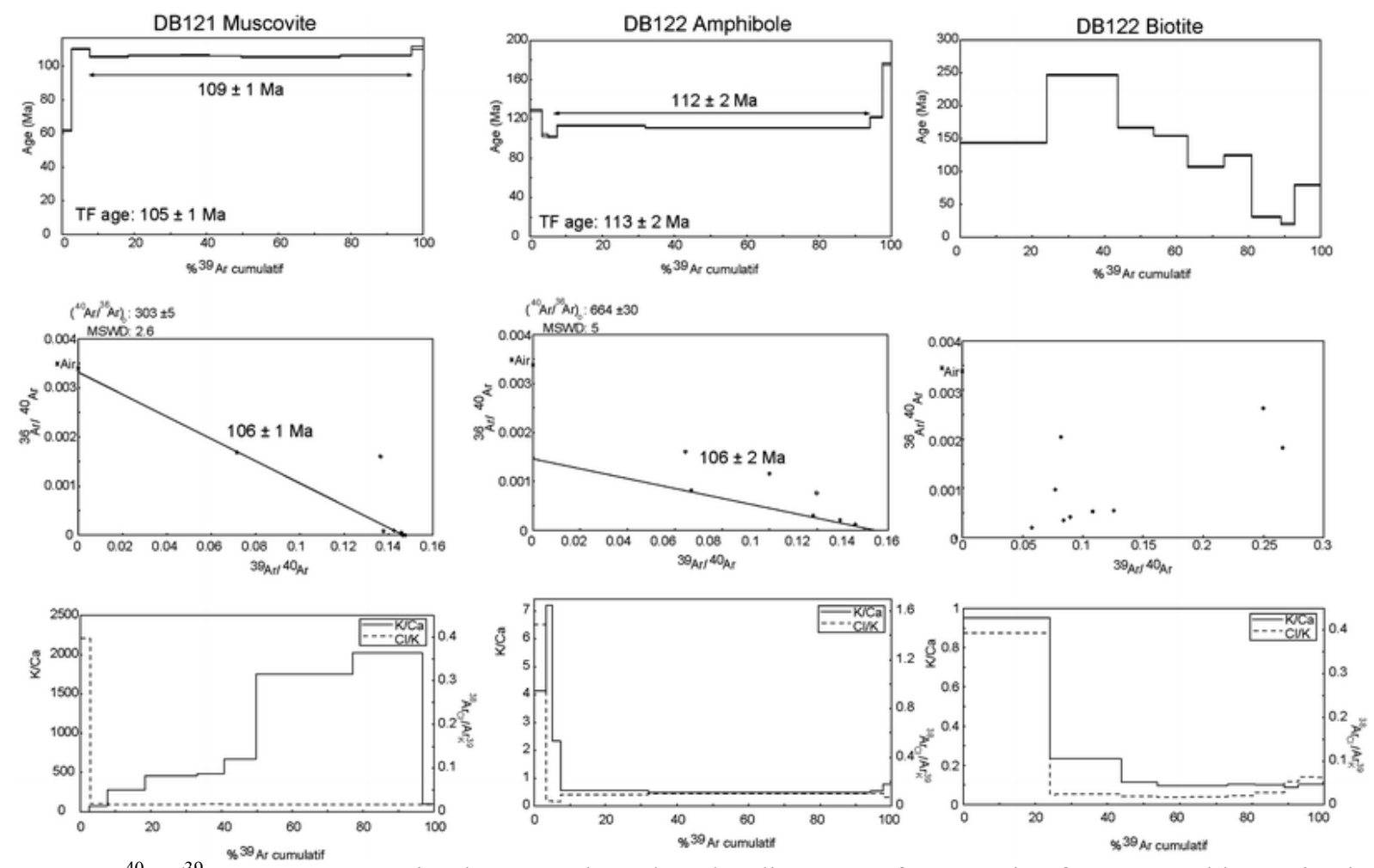

Fig. $13{ }^{40} \mathrm{Ar} /{ }^{39} \mathrm{Ar}$ age spectra, isochron result and $\mathrm{Ca} / \mathrm{K}$ diagrams of muscovite from a marble restite in migmatite (DB 121), biotite and amphibole from that granodiorite (DB 122) which includes the eclogitic xenolith described in this paper. The samples coming from the Central Dabieshan Domain are located in Fig. 1. In spite of poorly defined plateau for the biotite, Cretaceous ages are indicated by muscovite and amphibole

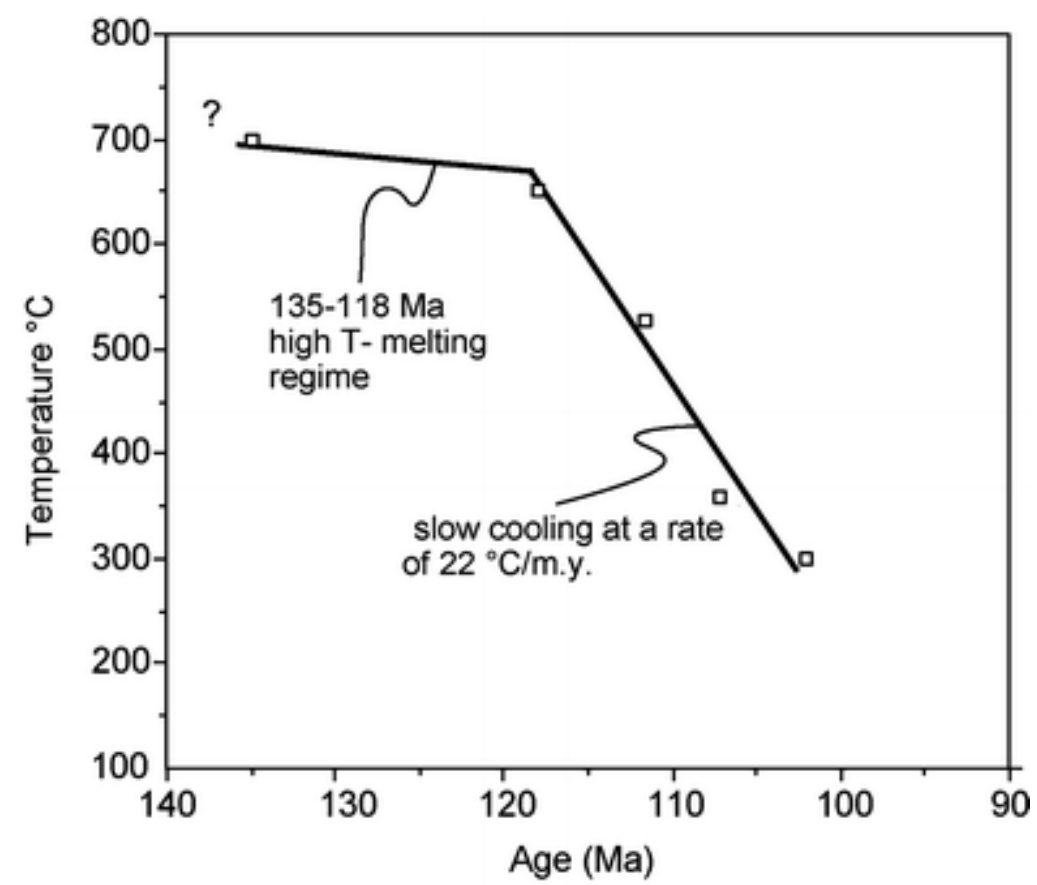

Fig. 14 Late Mesozoic thermal history of the Central Dabieshan Domain. The first stage from 135 to $118 \mathrm{Ma}$ indicates high temperature conditions coeval with crustal melting and migmatization. The second part from 118 to $100 \mathrm{Ma}$ corresponds to the slow cooling rate of $22^{\circ} \mathrm{C} / \mathrm{my}$. Temperature of $650^{\circ} \mathrm{C}$ was used for the $\mathrm{U} / \mathrm{Pb}$ system in titanite (Zhang and Schärer 1999 ), $530^{\circ} \mathrm{C}$ for the $\mathrm{K}-\mathrm{Ar}$ chronometer in amphiboles, $350^{\circ} \mathrm{C}$ for muscovite (Purdy and Jäger 1976), and $300^{\circ} \mathrm{C}$ for $\mathrm{Rb} / \mathrm{Sr}$ in biotite 
(a)

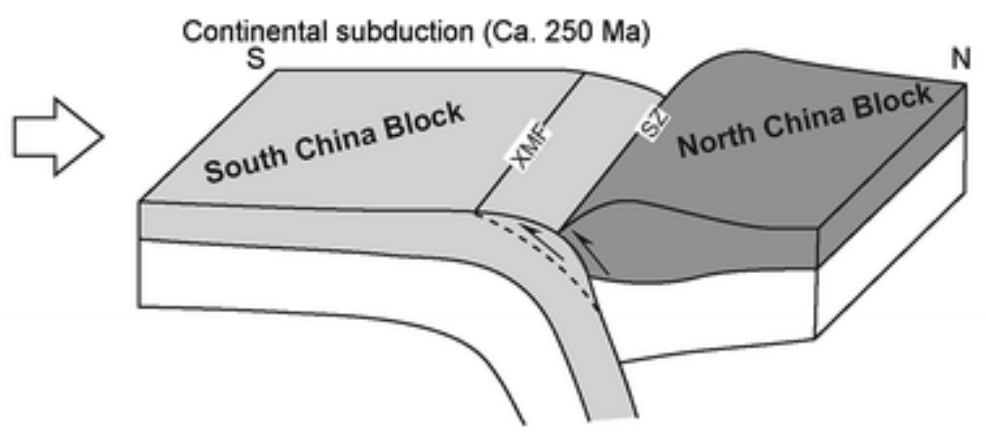

(b)

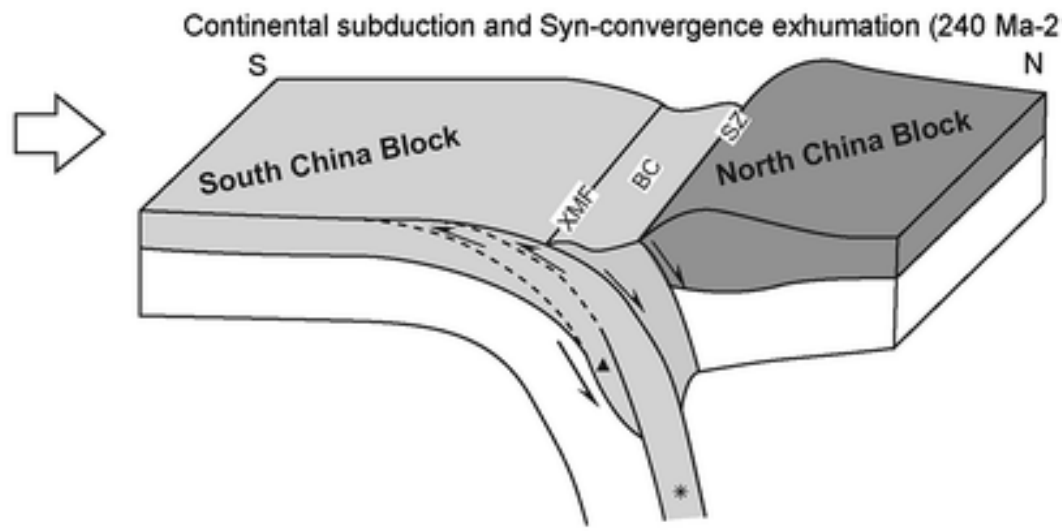

(c)

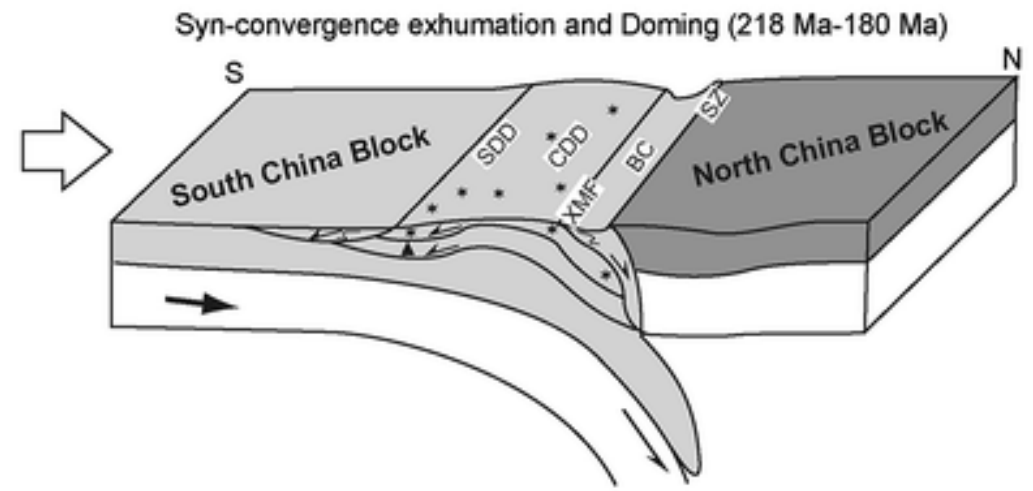

(d)

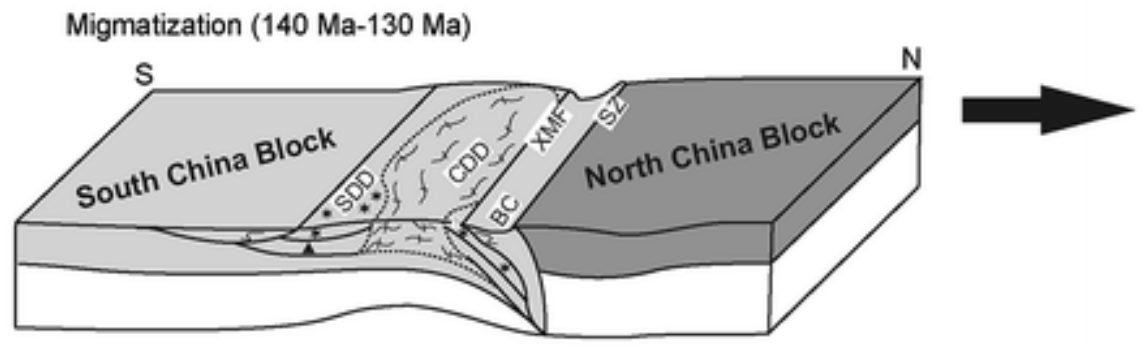

(e)

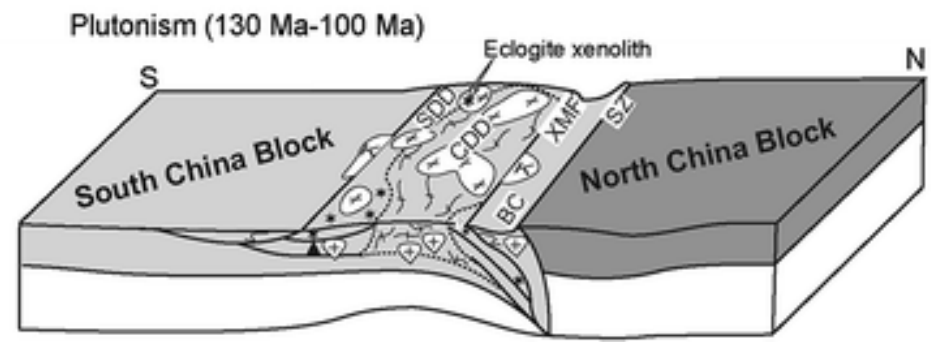

Fig. 15 Tentative geodynamic model of the Dabieshan with emphasis on the basis of the eclogite xenolith in the Mesozoic granite of Central Dabieshan Domain, the convergence between North and South China Block leads to oceanic (a) and continental subduction (b). c During the convergence and exhumation, the doming forms in the 
Central domain. The eclogitized continental crust occupied the area corresponding to the Central and South Domain. d, e the final architecture of the Dabieshan massif was completed during the Cretaceous through migmatization and plutonism. The Moho offsets below the suture and the southern boundary of the Dabieshan orogen were inferred from the geophysical surveys (Yuan et al. 2003; Dong et al. 2004) (Triangle and star-shape symbol show different situations and eclogite during the plate subduction; $B C$ Beihuaiyang Complex, $C D D$ Central Dabieshan Domain, SDD South Dabieshan Domain, SZ Suture Zone, XMF Xiaotian-Mozitan fault) 


\section{Tables}

Table 1 Representative analyses of garnet, omphacite and epidote in an eclogite xenolith from the Central Dabieshan Domain

\begin{tabular}{|c|c|c|c|c|c|c|}
\hline \multirow{2}{*}{ Minetal mode } & \multicolumn{3}{|l|}{ Garnet } & \multicolumn{2}{|c|}{ Omphacite } & \multirow{2}{*}{ Epidote matrix } \\
\hline & Core & Mantle & Rim & inc & Matrix & \\
\hline \multicolumn{7}{|l|}{$w t \%$} \\
\hline $\mathrm{SiO}_{2}$ & 37.8 & 37.9 & 38.0 & 55.2 & 55.9 & 37.7 \\
\hline $\mathrm{TiO}_{2}$ & 0.18 & 0.08 & 0.01 & 0.09 & 0.04 & 0.09 \\
\hline $\mathrm{Al}_{2} \mathrm{O}_{3}$ & 21.2 & 21.2 & 21.5 & 9.42 & 9.75 & 25.6 \\
\hline $\mathrm{Cr}_{2} \mathrm{O}_{3}$ & 0.00 & 0.00 & 0.00 & 0.00 & 0.00 & 0.02 \\
\hline $\mathrm{Fe}_{2} \mathrm{O}_{3}{ }^{\mathrm{c}}$ & & & & & & 10.1 \\
\hline $\mathrm{FeO}^{\mathrm{a}}$ & 25.6 & 28.2 & 27.6 & 6.50 & 5.40 & \\
\hline $\mathrm{MnO}$ & 3.64 & 0.25 & 0.34 & 0.01 & 0.04 & 0.12 \\
\hline $\mathrm{MgO}$ & 0.97 & 2.76 & 4.03 & 8.14 & 8.36 & 0.05 \\
\hline $\mathrm{CaO}$ & 10.83 & 9.18 & 7.63 & 12.9 & 12.9 & 22.9 \\
\hline $\mathrm{Na}_{2} \mathrm{O}$ & 0.00 & 0.00 & 0.00 & 7.31 & 7.11 & 0.00 \\
\hline $\mathrm{K}_{2} \mathrm{O}$ & 0.00 & 0.00 & 0.00 & 0.00 & 0.00 & 0.00 \\
\hline Total & 100.22 & 99.57 & 99.11 & 99.57 & 99.50 & 96.58 \\
\hline \multicolumn{7}{|l|}{ Formulae } \\
\hline $\mathrm{Si}$ & 3.01 & 3.01 & 3.01 & 1.98 & 2.00 & 3.00 \\
\hline $\mathrm{Ti}$ & 0.01 & 0.01 & 0.00 & 0.00 & 0.00 & 0.01 \\
\hline $\mathrm{Al}$ & 1.99 & 1.98 & 2.01 & 0.4 & 0.41 & 2.40 \\
\hline $\mathrm{Cr}$ & 0.00 & 0.00 & 0.00 & 0.00 & 0.00 & 0.00 \\
\hline $\mathrm{Fe}^{3+}$ & & & & $0.11^{\mathrm{b}}$ & $0.08^{\mathrm{b}}$ & $0.61^{\mathrm{c}}$ \\
\hline $\mathrm{Fe}^{2+\mathrm{a}}$ & 1.70 & 1.87 & 1.83 & $0.09^{b}$ & $0.08^{b}$ & \\
\hline $\mathrm{Mn}$ & 0.25 & 0.02 & 0.02 & 0.00 & 0.00 & 0.01 \\
\hline $\mathrm{Mg}$ & 0.12 & 0.33 & 0.48 & 0.44 & 0.45 & 0.01 \\
\hline $\mathrm{Ca}$ & 0.92 & 0.78 & 0.65 & 0.50 & 0.49 & 1.95 \\
\hline $\mathrm{Na}$ & 0.00 & 0.00 & 0.00 & 0.51 & 0.49 & 0.00 \\
\hline $\mathrm{K}$ & 0.00 & 0.00 & 0.00 & 0.00 & 0.00 & 0.00 \\
\hline
\end{tabular}

inc inclusion in garnet mantle

${ }^{\text {a }}$ Total iron as FeO

${ }^{\mathrm{b}} \mathrm{C}$ alculated values (see text)

${ }^{\mathrm{c}} \mathrm{Total}$ iron as $\mathrm{Fe}_{2} \mathrm{O}_{3}$ 
Table 2 Representative analyses of amphiboles in an eclogite xenolith from the Central Dabieshan Domain

\begin{tabular}{|c|c|c|c|c|c|c|c|c|c|}
\hline \multirow{2}{*}{\begin{tabular}{|l|} 
Mode \\
Mineral \\
\end{tabular}} & \multirow{2}{*}{\begin{tabular}{|l} 
inc \\
Bar
\end{tabular}} & \multirow{2}{*}{\begin{tabular}{|l|} 
(Core) \\
Gln
\end{tabular}} & \multicolumn{3}{|c|}{ Matrix } & \multirow{2}{*}{\begin{tabular}{|l|} 
(Rim) \\
Tar
\end{tabular}} & omp & \multirow{2}{*}{\begin{tabular}{|l} 
Grt \\
Prg
\end{tabular}} & \\
\hline & & & Win & Bar & Kat & & Ed & & \\
\hline \multicolumn{9}{|l|}{$w t \%$} & \\
\hline $\mathrm{SiO}_{2}$ & 50.9 & 57.8 & 54.3 & 51.8 & 46.8 & 43.3 & 45.4 & 38.9 & \\
\hline $\mathrm{TiO}_{2}$ & 0.16 & 0.01 & 0.09 & 0.07 & 0.12 & 0.30 & 0.10 & 0.00 & \\
\hline $\mathrm{Al}_{2} \mathrm{O}_{3}$ & 8.35 & 11.0 & 6.83 & 8.07 & 12.6 & 15.0 & 12.0 & 19.2 & \\
\hline $\mathrm{Cr} 2 \mathrm{O} 3$ & 0.01 & 0.00 & 0.04 & 0.00 & 0.00 & 0.02 & 0.00 & 0.03 & \\
\hline $\mathrm{FeO}^{\mathrm{a}}$ & 14.8 & 7.52 & 10.4 & 10.6 & 12.5 & 21.0 & 11.8 & 19.8 & \\
\hline $\mathrm{MnO}$ & 0.16 & 0.01 & 0.03 & 0.04 & 0.06 & 0.10 & 0.00 & 0.04 & \\
\hline $\mathrm{MgO}$ & 11.8 & 12.5 & 14.1 & 14.4 & 11.9 & 5.69 & 13.0 & 5.70 & \\
\hline $\mathrm{CaO}$ & 7.15 & 1.34 & 7.42 & 7.52 & 8.51 & 7.18 & 10.2 & 9.82 & \\
\hline $\mathrm{Na}_{2} \mathrm{O}$ & 4.02 & 7.03 & 3.82 & 4.11 & 4.39 & 5.38 & 3.80 & 4.27 & \\
\hline $\mathrm{K}_{2} \mathrm{O}$ & 0.06 & 0.04 & 0.02 & 0.05 & 0.09 & 0.04 & 0.03 & 0.06 & \\
\hline Total & 97.41 & 97.25 & 97.04 & 96.62 & 96.98 & 98.05 & 96.29 & 97.82 & \\
\hline \multicolumn{9}{|c|}{ Formulae } & \\
\hline $\mathrm{Si}$ & 7.27 & 7.85 & 7.66 & 7.34 & 6.76 & 6.44 & 6.65 & 5.84 & \\
\hline $\mathrm{Ti}$ & 0.02 & 0.00 & 0.01 & 0.01 & 0.01 & 0.03 & 0.01 & 0.00 & \\
\hline $\mathrm{Al}$ & 1.41 & 1.76 & 1.14 & 1.35 & 2.15 & 2.63 & 2.07 & 3.40 & \\
\hline $\mathrm{Cr}$ & 0.00 & 0.00 & 0.00 & 0.00 & 0.00 & 0.00 & 0.00 & 0.00 & \\
\hline $\mathrm{Fe}^{3+b}$ & 0.69 & 0.29 & 0.22 & 0.54 & 0.40 & 0.57 & 0.32 & 0.50 & \\
\hline $\mathrm{Fe}^{2+\mathrm{b}}$ & 1.08 & 0.57 & 1.01 & 0.71 & 1.11 & 2.05 & 1.12 & 1.98 & \\
\hline $\mathrm{Mn}$ & 0.02 & 0.00 & 0.00 & 0.01 & 0.01 & 0.01 & 0.00 & 0.01 & \\
\hline $\mathrm{Mg}$ & 2.51 & 2.53 & 2.97 & 3.04 & 2.56 & 1.26 & 2.84 & 1.28 & \\
\hline $\mathrm{Ca}$ & 1.10 & 0.20 & 1.12 & 1.14 & 1.32 & 1.15 & 1.60 & 1.58 & \\
\hline $\mathrm{Na}$ & 1.11 & 1.85 & 1.05 & 1.13 & 1.23 & 1.55 & 1.08 & 1.24 & \\
\hline $\mathrm{K}$ & 0.01 & 0.01 & 0.00 & 0.01 & 0.02 & 0.01 & 0.01 & 0.01 & \\
\hline
\end{tabular}


Table 3 Mineral parageneses for the different stages of evolution of eclogite xenolith from the Central Dabieshan Domine

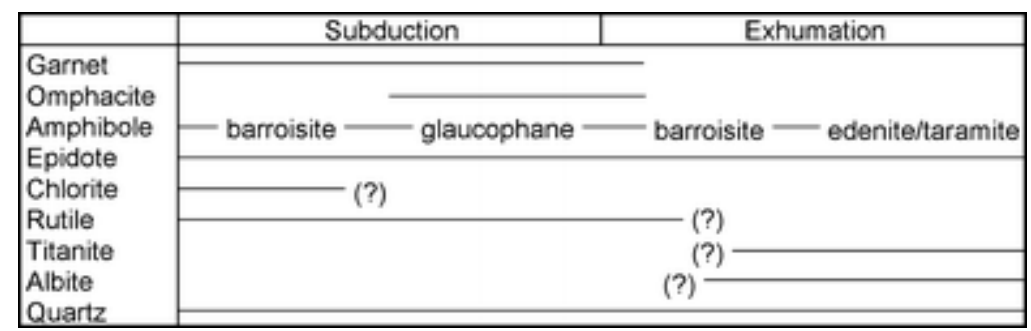



Table $4{ }^{40} \mathrm{Ar} /{ }^{39} \mathrm{Ar}$ analytical results from the anatextic granite and marble of Central Dabieshan Domain

\begin{tabular}{|c|c|c|c|c|c|c|c|c|c|c|}
\hline Temp & ${ }^{40} \mathrm{Ar} /{ }^{39} \mathrm{Ar}$ & ${ }^{38} \mathrm{Ar} /{ }^{39} \mathrm{Ar}$ & ${ }^{37} \mathrm{Ar} /{ }^{39} \mathrm{Ar}$ & $\begin{array}{l}\left.{ }_{\left(10^{-3}\right.}{ }^{-3}\right) \\
{ }^{39} \mathrm{Ar}\end{array}$ & $\begin{array}{l}{ }^{39} \mathrm{Ar} \\
\left(10^{-14} \mathrm{~mol}\right)\end{array}$ & $\begin{array}{l}\mathbf{F}^{39} \mathrm{Ar} \\
\text { (released) }\end{array}$ & $\%^{40} \mathrm{Ar} *$ & ${ }^{40} \mathrm{Ar} * /{ }^{39} \mathrm{Ar}$ & $\begin{array}{l}\text { Age } \\
\text { (Ma) }\end{array}$ & \begin{tabular}{|lr} 
\pm & $1 \mathrm{~s}$ \\
(Ma) & \\
\end{tabular} \\
\hline $\begin{array}{l}\text { DB } \\
121\end{array}$ & $\begin{array}{l}\text { Muscovite } \\
(J=0.0089360)\end{array}$ & & & & & & & & & \\
\hline 688 & 7.323 & 0.396 & 1.156 & 11.904 & 1.61 & 2.57 & 46.49 & 3.91 & 61.99 & 0.41 \\
\hline 807 & 7.261 & 0.015 & 0.025 & 0.603 & 3.17 & 7.62 & 90.54 & 7.06 & 110.32 & 0.27 \\
\hline 855 & 6.781 & 0.014 & 0.007 & 0.000 & 6.73 & 18.34 & 96.04 & 6.75 & 105.66 & 0.32 \\
\hline 917 & 6.832 & 0.014 & 0.004 & 0.000 & 9.22 & 33.02 & 97.03 & 6.80 & 106.45 & 0.28 \\
\hline 949 & 6.841 & 0.014 & 0.004 & 0.000 & 4.85 & 40.75 & 94.92 & 6.81 & 106.58 & 0.43 \\
\hline 999 & 6.827 & 0.014 & 0.003 & 0.000 & 5.63 & 49.72 & 95.59 & 6.80 & 106.37 & 0.20 \\
\hline 1109 & 6.864 & 0.014 & 0.001 & 0.336 & 17.14 & 77.00 & 96.84 & 6.74 & 105.45 & 0.35 \\
\hline 1208 & 7.018 & 0.014 & 0.001 & 0.616 & 12.45 & 96.82 & 95.33 & 6.81 & 106.55 & 0.36 \\
\hline 1422 & 13.964 & 0.018 & 0.019 & 23.549 & 1.99 & 100.00 & 48.29 & 7.10 & 111.05 & 1.12 \\
\hline $\begin{array}{l}\mathrm{DB} \\
122 \\
\end{array}$ & $\begin{array}{l}\text { Amphibole } \\
(J=0.0089360)\end{array}$ & & & & & & & & & \\
\hline 693 & 15.506 & 1.493 & 0.466 & 24.949 & 0.22 & 3.38 & 50.13 & 8.27 & 128.64 & 1.09 \\
\hline 781 & 10.006 & 0.047 & 0.267 & 11.631 & 0.11 & 5.09 & 55.54 & 6.62 & 103.67 & 1.22 \\
\hline 893 & 8.340 & 0.039 & 0.827 & 6.384 & 0.16 & 7.44 & 67.08 & 6.51 & 102.02 & 0.80 \\
\hline 1004 & 7.688 & 0.097 & 3.442 & 2.205 & 1.63 & 31.97 & 92.41 & 7.24 & 113.13 & 0.43 \\
\hline 1107 & 7.324 & 0.105 & 3.946 & 1.578 & 4.12 & 94.05 & 95.74 & 7.09 & 110.85 & 0.28 \\
\hline 1212 & 8.420 & 0.103 & 3.578 & 2.824 & 0.23 & 97.59 & 80.37 & 7.80 & 121.63 & 0.61 \\
\hline 1425 & 14.921 & 0.073 & 2.477 & 12.446 & 0.16 & 100.00 & 65.75 & 11.45 & 175.75 & 1.22 \\
\hline \begin{tabular}{|l} 
DB \\
122
\end{tabular} & Biotite $(J=0.0089360)$ & & & & & & & & & \\
\hline
\end{tabular}




\begin{tabular}{|c|c|c|c|c|c|c|c|c|c|c|}
\hline Temp & ${ }^{40} \mathrm{Ar} /{ }^{39} \mathrm{Ar}$ & ${ }^{38} \mathrm{Ar} /{ }^{39} \mathrm{Ar}$ & ${ }^{37} \mathrm{Ar} /{ }^{39} \mathrm{Ar}$ & 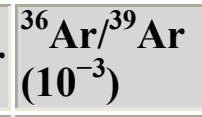 & 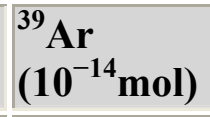 & $\begin{array}{l}\mathbf{F}^{39} \mathrm{Ar} \\
\text { (released) }\end{array}$ & $\%^{40} \mathrm{Ar} *$ & ${ }^{40} \mathrm{Ar} * /{ }^{39} \mathrm{Ar}$ & $\begin{array}{l}\text { Age } \\
\text { (Ma) }\end{array}$ & $\begin{array}{ll} \pm & 1 s \\
\text { (Ma) } & \end{array}$ \\
\hline 659 & 12.954 & 0.396 & 2.025 & 13.016 & 1.03 & 24.02 & 70.89 & 9.28 & 143.78 & 0.69 \\
\hline 835 & 11.713 & 0.021 & 17.241 & 6.959 & 0.43 & 53.72 & 88.79 & 10.84 & 166.73 & 0.81 \\
\hline 893 & 11.013 & 0.019 & 20.434 & 8.088 & 0.40 & 63.04 & 86.60 & 10.01 & 154.57 & 0.52 \\
\hline 946 & 7.835 & 0.020 & 20.555 & 7.839 & 0.44 & 73.16 & 82.55 & 6.86 & 107.38 & 0.66 \\
\hline 1106 & 3.707 & 0.030 & 19.447 & 10.074 & 0.34 & 88.86 & 44.74 & 1.94 & 31.01 & 0.71 \\
\hline 1210 & 3.940 & 0.055 & 22.346 & 13.741 & 0.17 & 92.77 & 23.57 & 1.27 & 20.43 & 1.36 \\
\hline 1400 & 12.017 & 0.068 & 18.902 & 28.044 & 0.31 & 100.00 & 38.30 & 5.05 & 79.66 & 0.86 \\
\hline
\end{tabular}

